\title{
urbanismo conveniente luso-brasileiro na formação de povoações em Minas Gerais no século XVIII
}

\begin{abstract}
Rodrigo Almeida Bastos ${ }^{1}$
RESUMO: A formação de povoações na capitania de Minas Gerais no século XVIII estava condicionada a preceitos de decoro, conveniência e adequação. Esses preceitos constituíam regras, doutrinas e costumes muito relevantes à arte luso-brasileira de edificar arquiteturas e cidades naquele tempo. A consideração histórica desses aspectos nos conduz à revisão crítica de uma série de compreensões consolidadas na historiografia, como, por exemplo, a de que essas povoações seriam espontâneas, irregulares e desordenadas. Pela importância com que se evidenciam nas povoações remanescentes, nos tratados artísticos e nos documentos coevos, tais aspectos nos levam a cogitar em uma verdadeira arte de povoar fundamentada nesses valores e costumes, arte a que denominamos urbanismo conveniente luso-brasileiro.
\end{abstract}

PALAVRAS-CHAVE: Urbanismo colonial. Minas Gerais. Decoro. Conveniência.

ABSTRACT: The settlement of villages in the old colonial province of Minas Gerais obeyed certain principles of what was considered decent, convenient and adequate. Such principles were based on rules, doctrines and habits inherent to the Luso-Brazilian architecture of that time. The historical analysis of these aspects leads to a critical review of some consolidated assumptions in historiography, such as the one for which the settlements aforementioned would have appeared in a spontaneous, irregular and disordered fashion. Because they are evident in the remaining settlements and period art treatises and documents, these aspects lead to the consideration of a true art of populating, based on certain values and habits, which we call convenient Luso-Brazilian urbanism.

KEYWORDS: Colonial urbanism. Minas Gerais. Decorum. Convenience.

Chamo de urbanismo conveniente luso-brasileiro o conjunto de aspectos e fatores envolvidos nos processos de implantação, aumento e conservação de
1. Docente do Departamento de Arquitetura da Universidade Federal de Santa Catarina". Email: <rodrigobastos. arq@gmail.com>. 
2. Ver Rodrigo Almeida Bastos (2003).

3.É muito eloquente a definição que, no início do século XVIII, o jesuíta Luis Gonzaga dá para "decoro" em seu Tratado de Arquitetura, "Apparencia, decoro, e fermosura daplanta, ou praça, se equivoca também m.to com Eurithmia [...], porem tem sua differença; porq a Eurithmia so trata do decoro da boa destribuição das suas partes, emqt.o [enquanto] ao Lugar qham de ter no risco (entre si). Mas o Decoro he apropried.e [propriedade] das partes da praça per ordem aoSitio, q se tem escolhido - por ordem ao Costume Comq se dispoem, e per ordem (aauthoridade) anatureza do (com) q se faz [.] Sirva [?] de exemplo uma praça q se manda fazer, o engenheyro, busca este sitio, e Lugar da Fortificação a onde possa ser conveniente, (descuberto o Sitio o fortifica pello costume, ou Methodo Lusitano seguindo os seos preceytos, mais Conforme a natureza da praça, q se pertende fazer. E esta planta tira a determinado Sitio com determinado methodo, q tem sua certa natureza [.] Se chama decoro da planta, ou planta decoroza.) busca este o sitio mais apto $\mathrm{p}^{\mathrm{a}}$ o fim $\mathrm{q}$ se pertende, dispoem as partes da praça seguindo hum Costume, ou methodo de fortificar, e segundo este vay dando a cada uma das partes, oque elles per Sua natureza pedem Como escarpa ao muro, contraescarpa ao fosso \&a. e a planta, q representa tudo isto se diz decoroza". Cf Luis Gonzaga ([17--?], fl. 40). povoações em que rezavam costumes e preceitos muito antigos de decoro, conveniência e adequação. Com efeito, o costume português de edificar praças e povoações - que se formou em muitos séculos de discursos letrados e experiências práticas na arte de construir - adaptava-se às várias circunstâncias encontradas nos sítios onde as implantavam. E isso não deve ter sido apenas por haver, como já se escreveu, uma "tendência" portuguesa para a adaptação. Estudos sobre a cultura lusitana indicam tal tendência, mas há que se considerar que ela também vinha estimulada, por assim dizer, internamente, através de um preceito secular das artes, da ética e da arquitetura. Esse preceito secular era o decoro, que fundamentava os processos de adaptação dessas artes desde a antiguidade até, pelo menos, o final do século XVIII, visando sempre a âmbitos variados de conveniência; no caso específico da arquitetura, principalmente à formosura, à decência e à comodidade de edifícios e cidades.

E a doutrina do decoro parece ter sido mesmo um dos aspectos mais importantes do processo de povoamento ou urbanização em Minas Gerais. É o que pretendi demonstrar na dissertação de mestrado da qual este texto resulta - $A$ arte do urbanismo conveniente: o decoro na implantação de novas povoações em Minas Gerais na primeira metade do século XVIIIR. A consideração do decoro contribuiu para a consolidação de uma política de expansão e conservação das conquistas e povoações mineiras, baseada na atenção aos costumes, às condições dos sítios e dos edifícios já construídos; contribuiu também para a consolidação de uma disposição portuguesa pela adequação aos contextos e circunstâncias coloniais, efetivada em povoações cuja regularidade primordial não deveria advir senão justamente dessa decorosa disposição pela adequação, e não apenas da geometria. Os tratados de arquitetura e engenharia militar antigos e modernos, estrangeiros e portugueses -, que subsidiavam a formação do corpo técnico responsável pela fábrica construtiva na metrópole e nas colônias, reafirmavam a consideração primordial do decoro "por ordem" aos sítios, construções preexistentes e costumes construtivos, "por ordem" às circunstâncias e costumes das pessoas que sobre eles se acomodavam ${ }^{3}$.

A partir dos setecentos, Portugal estabeleceu-se definitivamente sobre as conquistas e "novos descobrimentos" do sertão mineiro, território onde a "acomodação", o "sossego" e a "permanência" dos povos e povoações passaram a ser fatores decisivos. Incentivando-os, pois, necessariamente, procurou-se então prudentemente conciliar as conveniências metropolitanas e as conveniências coloniais, concentrando-as em vilas dotadas de um organismo administrativo municipal - a Câmara -, ao qual tocava significativa responsabilidade pelo zelo e coordenação das atividades concernentes à res publica edificada. Assim, "novas povoações" fundaram-se e se implantaram sobre povoações preexistentes; foram requeridas novas estruturas urbanas, arruamentos - e edifícios convenientes e proporcionados, mais seguros, condignos e ornados -, enquanto a sociedade se acomodava no seio das irmandades leigas, ordens terceiras e confrarias.

Coordenado geralmente pelo governador da capitania, o processo de ereção das vilas foi um ato de vontade e necessidade políticas, quando se 
procurou eleger os sítios mais "convenientes" tanto à coroa quanto aos povos. Consequente a esse processo - que denominei de a invenção da permanência - instaurou-se uma nova disposição humana pelo lugar e ao lugar. Disposição pelo lugar porque aos colonos passava também a interessar uma condição de "permanência" nas povoações, estimulada pela concessão oficial de foros e privilégios e por outras formas de subsistência urbana emergentes, como o comércio e o oferecimento de trabalho livre; e disposição ao lugar porque a acomodação física dos moradores passava a ser regulada por novas formas de organização urbana condicionadas a requisições de conveniência, decência e dignidade que incluíam, por exemplo, maior rigor no alinhamento e continuidade dos arruamentos urbanos, novos ou restabelecidos, e a necessidade de licença oficial expedida pela câmara para construção de novas habitações e reforma (decente) das já existentes.

A ereção da vila determinava a instalação de uma câmara municipal que, a partir de então, concentrava outros três processos povoadores bastante significativos. Já sistematizei esses processos povoadores em outros textos, mas importa retornar a eles também aqui: 1. Adequação das estruturas construídas preexistentes: concessão de aforamentos sobre propriedades já estabelecidas pelos moradores; licenças para "retificação", reforma e reconstrução de casas mais seguras e decentes; realinhamento e "endireitamento" de ruas e "calçadas"; 2. "Aumento" da povoação (expansão física e "acrescentamento" de dignidade): abertura de novos arruamentos e logradouros; concessão de novos aforamentos para construção de novas casas; implantação de novos edifícios públicos, câmara e cadeia, pontes e chafarizes; ereção de capelas e igrejas, consolidação de largos e praças; 3. "Conservação": "reformas", "reparos", "consertos" e "correições" urbanas parcelares que visavam à manutenção de sua estrutura física e à correção de seu aspecto bem como à manutenção da "comodidade", da "decência" aparente, da "limpeza" e do "asseio" da povoação. Apesar de bem definidos, não se podem estabelecer delimitações rígidas entre esses processos. Ocorriam também simultaneamente, sendo complementares entre si. No mesmo momento em que novos arruamentos eram abertos, outros passavam por realinhamentos; enquanto novos aforamentos eram concedidos, outros moradores adquiriam licenças para reformar seus ranchos, transformá-los em casas, cobertas "de telha". A expansão física e a conservação da povoação representavam o vigor de sua permanência; tanto a eleição do sítio quanto a conservação das partes urbanas também poderiam implicar aumento de dignidade à povoação.

O decoro constituía uma orientação prudencial, desde o processo de escolha dos sítios, como veremos particularmente em Vila Rica, atual Ouro Preto, mas também um fim a ser alcançado. Ficou evidente o interesse da metrópole portuguesa pela "fundação", "aumento" e conservação" de povoações decorosas, dignas e cômodas aos seus habitantes. A utilidade e a aparência de suas estruturas e edifícios eram fatores igualmente considerados, tanto em relação aos públicos quanto aos particulares, como as próprias casas dos moradores, sobre as quais "vistorias" e "correições" dos vereadores e juízes da câmara impunham reformas 
4. O interesse metropolitano pela constituição de povoações e cidades "decorosas" não se restringiu ao território mineiro. Duas referências explicitam essas intenções em contextos também específicos, já dentro do período que se reconheceu como "pombalino", referente à presença significativa (entre 1750 e 1777) de Sebastião José de Carvalho e Mello, o Marquês de Pombal, primeiro ministro de D. José. Uma delas contempla os planos de renovação de Lisboa após o terremoto de 1755 , quando se definiram os princípios de um "plano global" para a cidade:"Ficando este sitio sendo cabeça, e parte principal da Corte, e Cidade de Lisboa, que por este novo plano ficará mais extensa, regular e decorosa". Cf. J. Baptista de Castro, apud Walter Rossa (1995, v. 3, p. 299). Outra referência está numa carta do próprio Marquês de Pombal enviada a Mendonça Furtado (Governador do Grão-Pará e Maranhão entre 1751 e 1758), na qual estariam incutidos alguns dos objetivos da política de fundação de cidades no território da Amazônia, dentre os quais: fazer multiplicar e florescer "povoações civiz, decoroas (sic) e uteis para o bem Comum da Coroa e dos Povos". Cf. Manuel C.Teixeira e Margarida Valla (1999, p. 254). Os autores confiaram esse documento à dissertação de mestrado de Renata Malcher de Araújo, publicada em 1998 , sobre as "cidades da Amazônia no século XVIII". Tais referências reafirmam a relevância de procurarmos compreender melhor os sentidos e as implicações da consideração do decoro em outras circunstâncias locais e temporais, não apenas na Minas Gerais do século XVIII.

5. Sobre essa discussão de regularidade nas povoações mineiras, cf. Rodrigo Almeida Bastos (2007). ou mesmo demolições, acaso comprometessem a "utilidade", a "aparência", a "beleza" e o "decoro" da povoação4.

O decoro das povoações, pois, constituía-se, aumentava e se conservava em vários aspectos: na "melhor" distribuição e implantação de suas partes sobre o sítio; na adequação mais conveniente das estruturas construídas, em consideração ao modo de vida e costumes estabelecidos ou acomodados; na crescente dignidade das construções e na decência dos arruamentos urbanos, alinhamento contínuo, limpeza e asseio (elegância e primor de fábrica); na comodidade por essas mesmas estruturas, oferecida no desempenho ordinário e cotidiano dos usos públicos; na representação de uma "regulação" metropolitana acordada e sustentada pelo pacto de sujeição - daí também a constante e necessária requisição de dignidade e decência dos arruamentos e construções; na constante (p)reparação, "conserto" e "correição" das partes urbanas, representativas todas, e em conjunto, do decoro e da conservação da povoação, que dava a representar o decoro ético-político e a conservação do próprio corpo do reino.

A compreensão desses processos revelou uma noção de cidade a ser conformada e conservada desde suas partes - íntegras e integradas entre si e ao todo. Nem sempre as providências poderiam ser efetivas, mas a regulação e os costumes orientavam a administração urbana. A cidade constituía um corpo urbano em constante acomodação, para aumento e conservação, para o qual se impunha uma necessária e permanente atenção ao âmbito construído. A cidade era composta e sustentada pela conveniência de intervenções parcelares constitutivas e mantenedoras da decência urbana. Tratando essas intervenções urbanas como intervenções parcelares - e não como "intervenções pontuais" -, podemos compreender melhor os procedimentos e os preceitos que orientavam suas efetivações, bem como uma verdadeira noção de cidade sob elas implícita. "Pontos" ou "intervenções pontuais" (expressão comum do urbanismo contemporâneo) podem não estimular a compreensão antiga de que o reino, suas conquistas e povoações se compunham de "partes" ordenadas de um "corpo político", análise coerente com o ambiente retórico e hierárquico setecentista lusobrasileiro.

Regularidade como observância às regras da arte

Investigando a confluência entre a doutrina do decoro e os processos de implantação de novas povoações mineiras nas primeiras décadas dos setecentos, fui levado a atentar para a existência de uma noção de "regularidade" mais abrangente do que aquela que tem sido frequentemente considerada e analisada nos estudos das vilas e cidades coloniais luso-brasileiras ${ }^{5}$. Naquele tempo, essa noção de regularidade foi declarada, por exemplo, pelo tratadista português Manoel de Azevedo Fortes e também por D. Raphael Bluteau: 
"regularidade" como "observância" aos princípios e "regras da arte"b. Pôde-se observar que realmente havia a intenção, é verdade - nas vilas e na única cidade mineira -, de se alcançar alguma "regularidade geométrica", manifesta em arruamentos bem alinhados e edifícios bem "proporcionados" e implantados. Mas essa regularidade consistia, todavia, numa regularidade geométrica possível, permanentemente condicionada a uma regularidade anterior, ou primordial, de adequação, prudente e estratégica, concernente a uma política de implantação de povoações e edifícios. Considerar uma regularidade primordial de adequação auxilia na compreensão dos diferentes, e até mesmo polêmicos, níveis de "regularidade geométrica" dessas povoações - notadamente singulares -, resultados dos vários convênios estabelecidos entre circunstâncias naturais, hábitos e necessidades humanas e construtivas, circunstâncias políticas e estruturas urbanas. Não se quer tratar aqui, contudo, de uma generalização. Estar consciente da abrangência de um processo não elimina a providência de estudos específicos sobre várias povoações e conjuntos arquitetônicos, e em boa medida chega mesmo a requerê-los.

Se considerarmos que a fábrica artístico-construtiva na primeira metade do século XVIII era entendida como a fábrica do "necessário" - ao lado da "conveniência", um dos termos mais recorrentes na documentação primária coeva -, poderíamos repensar a designação "espontânea": alcunha dada desde Salomão e, principalmente, Sylvio de Vasconcellos para as "novas povoações" mineiras. $\bigcirc$ "necessário" é - segundo Raphael Bluteau e seu Vocabulário, contemporâneo exatamente à implantação dessas povoações - justamente o "não espontâneo, o que é mister, o que convém"7. A congruência entre os princípios concernentes à doutrina do decoro e as indicações documentais recolhidas praticamente exige essa reflexão. Leva-nos, ainda, a tratá-las não mais como povoações "espontâneas", mas, antes, como povoações regulares e convenientes, povoações resultantes do que poderíamos chamar de urbanismo conveniente lusobrasileiro. E a conveniência, aqui, era a regra coeva capaz de abranger tanto os aspectos internos à fábrica construtiva - proporções, partes, capacidades, materiais adequados, competência de ornatos, aspectos técnico-construtivos e artísticos, consideração dos sítios e acomodação "por boa ordem" às preexistências construídas -, quanto, também, os aspectos externos referentes à satisfação da finalidade ética da obra, sua destinação, sua proveitosa adequação aos objetivos da política metropolitana e ao modo de vida colonial que se estabelecia.

Assim como fiz com o "decoro", seria importante que tentássemos reconstituir o sentido de outros preceitos e doutrinas antigos, de modo que pudéssemos escrever e reescrever a história da povoação de nosso território um pouco mais conscientes dos valores e preceitos coevos e também dos mitos anacrônicos - como a ordem e a regularidade eminentemente fundamentadas em valores geométricos - que ainda dominam a historiografia das cidades lusobrasileiras.
6. Cf. Raphael Bluteau, s. v. REGULAR; REGULARIDADE (1712,v. 7 , p. 206); e também Manoel de Azevedo Fortes,. O engenheiro portuguez (1728-1729), apud Beatriz Piccolotto Siqueira Bueno (2001, p. 486).

7. Cf. Raphael Bluteau. s. v. NECESSARIO. (1712, v. 5, p. 695); grifo nosso. 
8. Cf. Sylvio de Vasconcellos (1977, p. 44). Se Sylvio de Vasconcellos atualizou a denominação "capelas provisórias”, seu pai, Salomão de Vasconcelos, denominara os primeiros ranchos dos mineradores de "habitaçõesinhas provisorias". Cf. Salomão de Vasconcelos (1941, p. 241).

9.Até 1709 , uma só capitania englobava Rio de Janeiro, São Paulo e as Minas Gerais.Após 1709, separaram-se essas do Rio de janeiro. Em 1720, Minas Gerais constituiu uma capitania independente. Cf. José Pedro Xavier da Veiga (1998, p. 1025-1026).

10. Cf.José JoãoTeixeira Coelho (1994, p. 121-122).

11. O "termo" da vila consistia um território nos limites do qual a jurisdição administrativa da Câmara atuava, alcançando vastas extensões territoriais e, obviamente, inúmeros arraiais.

\section{caso paradigmático de Vila Rica, Ouro Preto}

Vila Rica sempre foi uma povoação bastante especial para a compreensão da arquitetura e do processo de implantação de povoações no século XVIII. É nela que se acomodaram alguns dos edifícios mais eloquentes do século XVIII na colônia, para além dos mitos que sobre ela repousam historiográficos, políticos, religiosos etc.

De um modo geral, as primeiras vilas se implantaram sobre assentamentos mineradores preexistentes que, logo nos prematuros anos da ocupação, constituíam arraiais concentrados comunitariamente em torno de capelas. Futuras matrizes, essas "capelas provisórias", no dizer de Sylvio de Vasconcellos", eram geralmente incorporadas a novas e mais "capazes" igrejas como suas capelas-mores. As criações dessas "novas povoações" eram passos decisivos na progressiva cadeia de estratégias e ordenações reinóis, e definiram de vez a intervenção metropolitana sobre o território de Minas Gerais. Vislumbrada precocemente a prosperidade das minerações, a metrópole foi obrigada a investir severamente na administração e na regulação da capitania, nesse momento ainda ligada a São Paulo?. E procurou não apenas implantar e manter a ordem nas novas "conquistas" e "descobrimentos", mas também arregimentar os modos mais competentes de arrecadar os tributos que pudessem sustentá-la economicamente; servindo-se, para tanto, de ordens e regulações fiscais exequíveis somente através da concentração urbana e administrativa, sustentada pela desejável permanência das povoações. Desde 1701, o governador Artur de Sá instituíra uma estrutura para arrecadação dos quintos, com superintendente, escrivães etc. ${ }^{10}$; mas um controle efetivo chegaria apenas com a concentração urbana e administrativa correspondente às primeiras vilas fundadas a partir de 1711 .

A implantação de uma vila instaurava uma série de providências, como o levantamento do pelourinho, instalação e construção da Câmara - acomodada provisoriamente em "casas de morada" -, cadeia, eventualmente um quartel etc. Essas providências "construtivas" tornavam cotidianamente efetiva - e evidentemente mais persuasiva - a "representação" do poder metropolitano. Para além das implicações concernentes à complexa política territorial ultramarina no século XVIII, e concentrando-nos no aspecto construído dos núcleos urbanos, estava instalada, a partir de então, uma estrutura administrativa com expressiva responsabilidade para intervir sobre o corpo construído das povoações. Dentre os objetivos principais dessa estrutura estava não apenas administrar a construção da vila e demais "arraiais" e "lugares" de seu "termo"1 l, como também "corrigir", "reedificar", "reformar" e "alinhar", como fosse possível, as primeiras ocupações, geralmente estabelecidas pelos primeiros moradores. Ocorre que, em Minas Gerais, uma especificidade influiu sobremaneira nas contingências e decisões vindouras: de forma até então inédita na colônia, o lugar da produção e o lugar da habitação estavam coincididos, reafirmando singularmente a concentração e o caráter urbano dessas povoações. 
fato de Vila Rica ter-se assentado em um sítio bastante acidentado pode ser considerado uma exceção dentro das recomendações autorizadas pelos tratados que fundamentaram a urbanística portuguesa desde o século XVI. Neles, os terrenos planos eram preferidos, propriedade que prometia redundar em implantações mais cômodas ao usufruto humano e também mais regulares em sua geometria. Entretanto, o convênio entre o sítio "não muito acomodado" de Vila Rica e as sucessivas estruturas urbanas setecentistas e oitocentistas que sobre ele se implantaram e nele se inseriram - casario, monumentos e ornatos, largos e arruamentos - caracterizou a atual Ouro Preto como uma das aglomerações humanas mais singulares que podemos reconhecer (Figuras 1 e 2).

Analisemos o "Termo da ereção de Vila Rica", de 8 de julho de 1711. Assinaram-no o então governador, Antonio de Albuquerque Coelho de Carvalho, o secretário-escrivão e alguns moradores reunidos em uma "Junta geral". A "Junta geral" era protocolo bastante comum, como se pode notar em outros documentos presentes no mesmo códice em que se encontram esse e outros termos de ereção de vilas, e amiúde solicitada quando da resolução de temas aparentemente mais complexos e de cunho bastante coletivo. Achei por bem transcrever todo o documento, guardando a grafia documental por fidelidade ao registro.

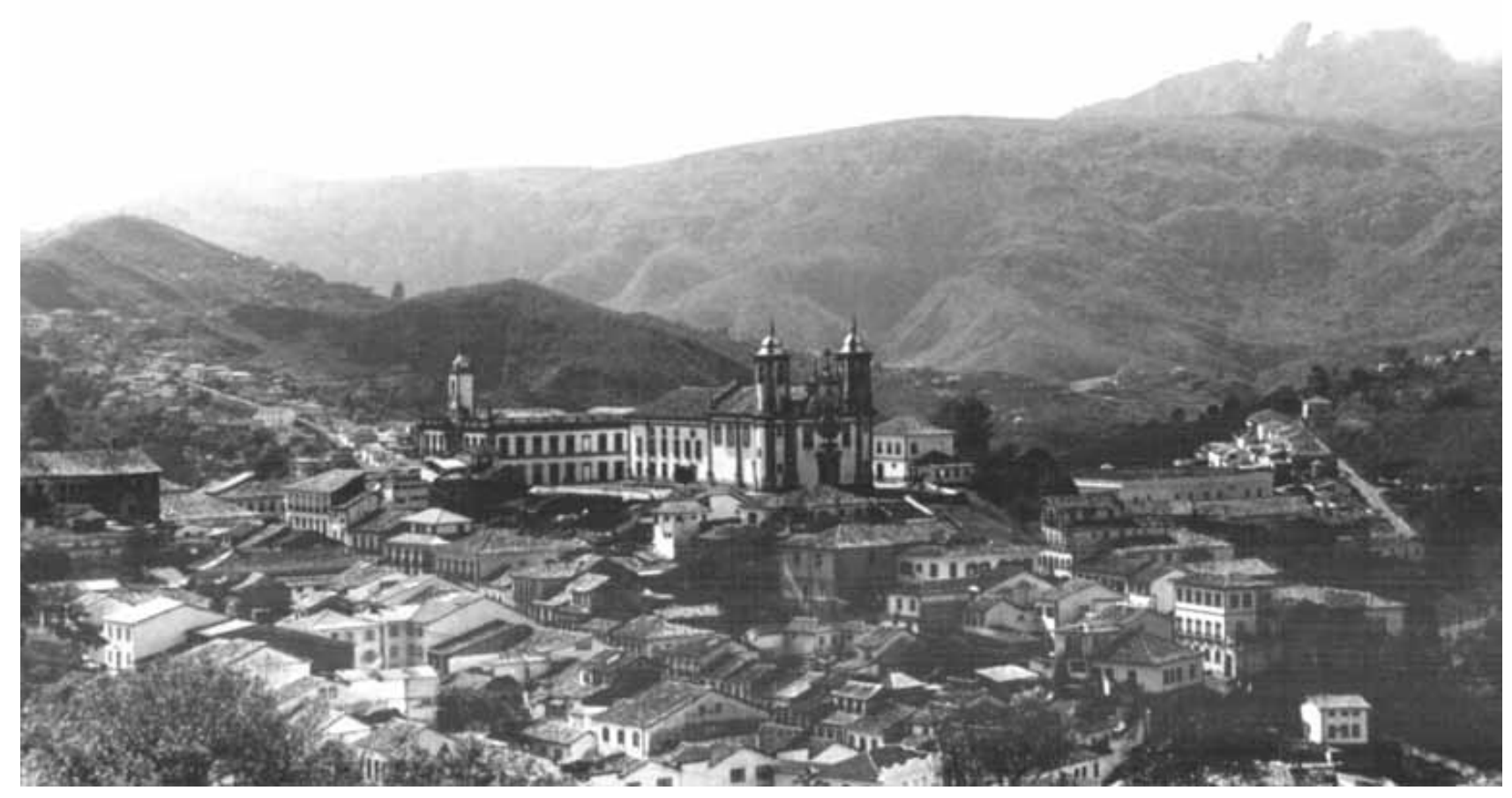

Figura 1: Vista de Ouro Preto, Arraial de Nossa Senhora do Pilar, abril de 2002. Fotografia e acervo do autor.

Annals of Museu Paulista. v. 20. n.1. Jan.-Jun. 2012. 


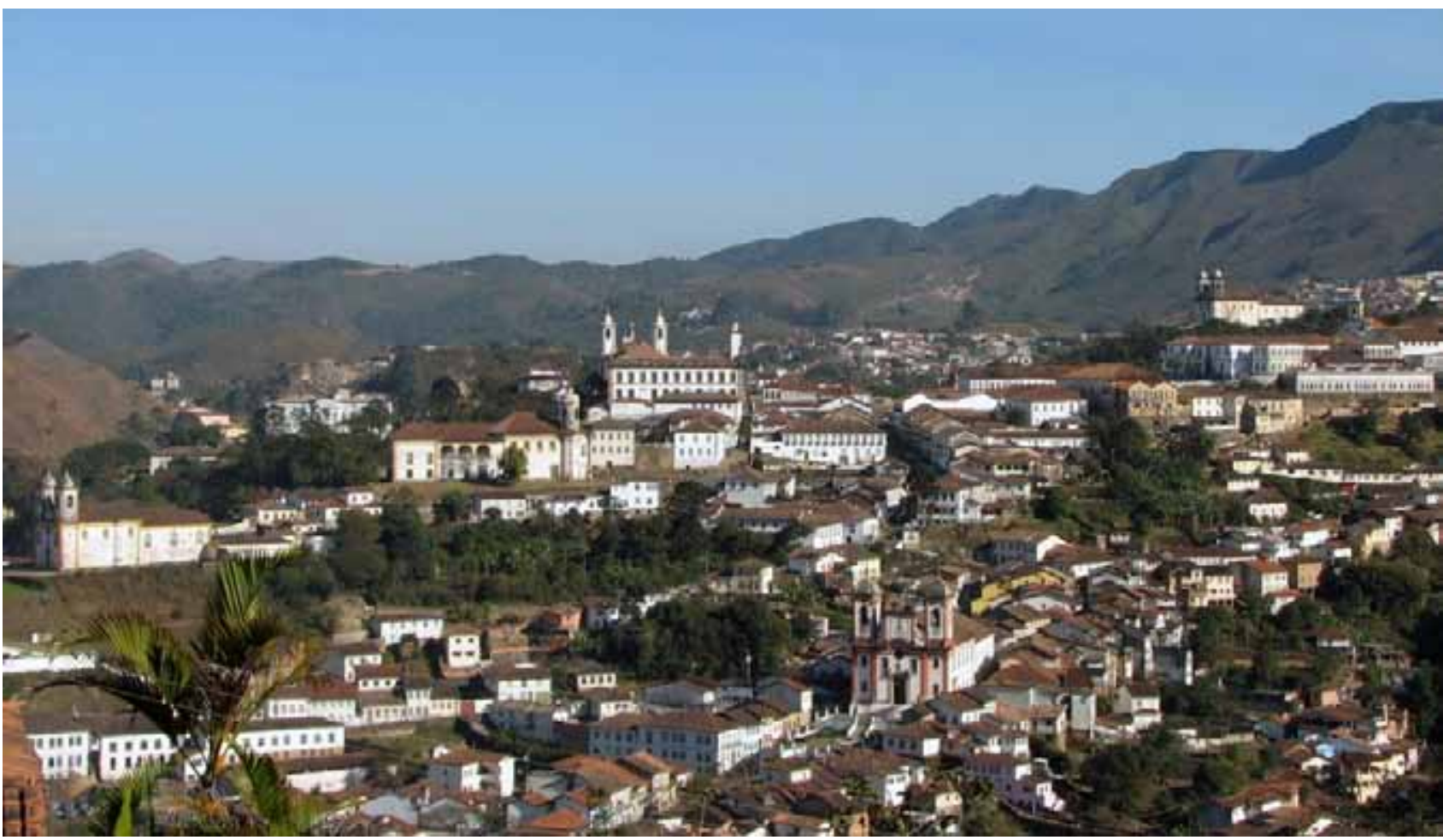

Figura 2: Vista de Ouro Preto, Arraial de Antonio Dias, abril de 2002. Fotografia e acervo do autor.

Termo da erecçao de Va Rica

Aos oito dias do mez de Julho do anno de mil settecentos e onze, neste Arrayal das minas g.es do oirro preto em as Cazas demorada, em q.' assiste o S. ${ }^{\circ}$ r Gov. ${ }^{\circ}$ e Cap.m Gn.al An. to de Albuquerq.e Coelho de Carvalho, achandosse prezentes em hua Junta g.al [Junta geral] q. ' o d. . S.or ordenou p. ${ }^{\circ}$ o mesmo dia, as Pessoas e moradores principaes deste d. ${ }^{\circ}$ Arrayal,

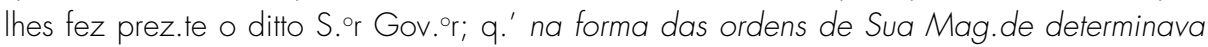
erigir neste mesmo Arrayal huâ nova povoação, e Villa p. ${ }^{a}$ q.' Seus moradores, e os mais de todo o destricto pudessem viver arreglados, e Sugeitos com toda alva forma ás Leys da Justiça, como S. Mag.de manda, e dezeja se conservem todos os Seus Vassallos nesta nova Conq.ta porq.' suppondo não achava o sitio m.to acomodado, attendendo ás riquezas q.' promettiaõ as minas, $q$.' ha tantos annos se lavraõ nestes morros e Ribr. ${ }^{\circ}$ s [Ribeiros] e ser a parte principal destas minas, aonde acode o Comercio, e fazendas, q.' delle, mana p. as mais e outras m.tas mais, q.' o tempo mostraria, se rezolvia a executalo assim e q.' todos deviaõ neste [?] dar o seu parecer, os quaes uniformem.te todos convieraõ em q.' neste d. ${ }^{\circ}$ Arrayal junto com o de An.to dias se fundasse a Villa pelas razões referidas; pois era o Sitio de mayores conveniencias, q. 'os Povos tinhaõ achado p. o Comercio; e q.' nesta forma se sogeitavaõ aviver todos como Leaes Vassalos de Mag.de Sogeitos ás suas Reaes Leys, e ás da Just. ${ }^{\circ}$ comtoda aobediencia, sem q.' selhes offereça duvida alguâ ao proposto pello d. . S. ${ }^{\circ}$ Gov. ${ }^{\circ}$, e por elle ditto s.or Governador foy respondido q.' visto, q.' todos assentavaõ [ilegível] em q.' fosse nestes Sitios e dois Arrayaes de oiro preto e An.to dias Levantada ad. ${ }^{a}$ Villa, era necess.r $r^{q}$.' Logo todos os $d$.'s moradores e pessoas deste povo fizessem eleyçaõ p. ${ }^{a}$ os off.es da Cam.ra [Câmara] della declarando todos juntamen.te, q.' desejavaõ, etinhaõ 
devoção de q.' se continuasse a invocaçaõ e Padroeyra desta Igreja do ouro preto Nossa S.r ${ }^{a}$ do Pilar, o nome da V. ${ }^{a}$ fosse Villa Rica d'Albuquerque; Ede como assim se ajustou tudo mandou o dito S. or Gov. ${ }^{\circ r}$ fazer este termo q.' assignaraõ os assistentes sobred. 'os. E eu Manoel Pegado Secretr. ${ }^{\circ}$ deste Governo o escrevi. [Assinaturas] ${ }^{12}$.

Na consideração às "conveniências"13 dos moradores o documento localiza o argumento e justificativa principais para se implantar a nova vila sobre o sítio resultante da comunhão entre os dois arraiais: Nossa Senhora do Pilar de Ouro Preto e Nossa Senhora da Conceição de Antônio Dias ${ }^{14}$. Concentravam os dois arraiais e os denominavam suas respectivas matrizes, tendo a meio-caminho o cume ainda desocupado do Morro de Santa Quitéria, onde atualmente está a Praça Tiradentes. $\bigcirc$ governador deve ter declarado explicitamente à Junta, como sugere o termo de ereção, que "não achava o sítio muito acomodado", mas atendeu finalmente à resolução com que os moradores "uniformemente todos convieram": fundar a vila junto aos dois arraiais "pois era o sítio de maiores conveniências que os povos tinham achado para o comércio". $\bigcirc$ "desejo" de Sua Majestade era declarado "conservarem-se ... todos os seus vassalos nesta nova Conquista", e, pelo que indica o documento, a determinação da Vila pairava especificamente sobre o arraial de Nossa Senhora do Pilar - "na forma das ordens de Sua Majestade" -, mas a decisão recaiu mesmo sobre a comunhão dos arraiais.

Minha tese é a de que Antonio de Albuquerque previu, sim, a futura centralização da vila sobre o cume do morro que dividia os dois arraiais, e também a sua consolidação como lugar público e de concentração administrativa por excelência; sobretudo estrategicamente, pois, além de constituir um centro aproximadamente geométrico, sua proeminência topográfica proporcionava amplo domínio visual sobre os arraiais, com suas igrejas-matrizes situadas em cotas bem mais baixas. Tanto que, no decorrer do século XVIII, instalaram-se na praça definitivamente o Palácio dos Governadores (ca. 1746) e a Casa de Câmara e Cadeia (ca. 1784). O palácio, ainda que apresente adequado caráter residencial, foi implantado como uma verdadeira fortificação, "risco" do sargentomor e engenheiro militar José Fernandes Pinto Alpoim, em 1741, com "arrematação" de Manuel Francisco Lisboa em 1745. Importa notar que o próprio rei D. João V redigira "instruções" decorosas sobre o lugar, o modo de implantação e a "aparência" das residências a serem construídas para assistir os governadores. No "Regimento" destinado ao governador Martinho de Mendonça - 30 de outubro de 1733, alguns anos antes do risco de Alpoim -, o rei recomendou que o dito governador procurasse se informar "do Lugar, e sítio mais commodo, p." assistencia dos futuros governadores, e do modo, e despeza com q.e se thes possa fazer habitação, q.e com apparencias de caza, tenha segurança e utilidade de fortaleza"15, o que realmente se conformou em Vila Rica (Figuras 3 e 4).

Retornemos ao processo de ereção da vila. Bastante apreciável é o fato de Antonio de Albuquerque também possuir experiência militar e, antes de
12. Cf.APM SC 06, f. 20, 20v, 21. Apesar de os termos de ereção das vilas mineiras se encontrarem publicados há uma centena de anos nas revistas do Arquivo Público Mineiro, procurei acessar os documentos originais. Nessas transcrições publicadas de vários documentos, encontram-se equívocos, risco a que todo pesquisador se sujeita em trabalho tão delicado.

13. Bluteau registrou para o termo "conveniencia" o sentido de "utilidade, enterece. Utilitas, atis. [...] Commodum". O "conveniente" é o que "convem a alguem, ou a alguma cousa".Cf. Raphael Bluteau, s. v. CONVENIENCIA (1712,v. 2, p. 515-517)

14. Nossa Senhora da Conceição era a padroeira da Ordem de Cristo, cujo Grão-mestre era o próprio rei. Um dos primeiros mineradores a se assentar na região foi Antônio Dias. Ele, bem como o Padre Faria e Manuel Garcia, divide junto aos historiadores as responsabilidades pela "redescoberta" dos veios na região de Ouro Preto.O pico do Itacolomi, sobranceiro a ela, representava o luzeiro mais significativo, na procura do qual as bandeiras depositavam as maiores esperanças. Ver Diogo de Vasconcellos (1948); e também Manuel Bandeira (2000)

15. REGIM.T T $^{\mathrm{o}}$ ou Instrucção que trouxe o Governador Martinho de Mendonça de Pina e de Proença (1898, p. 87). Recorri ao Regimento graças a uma referência em Sylvio de Vasconcellos (1977, p. 30). 


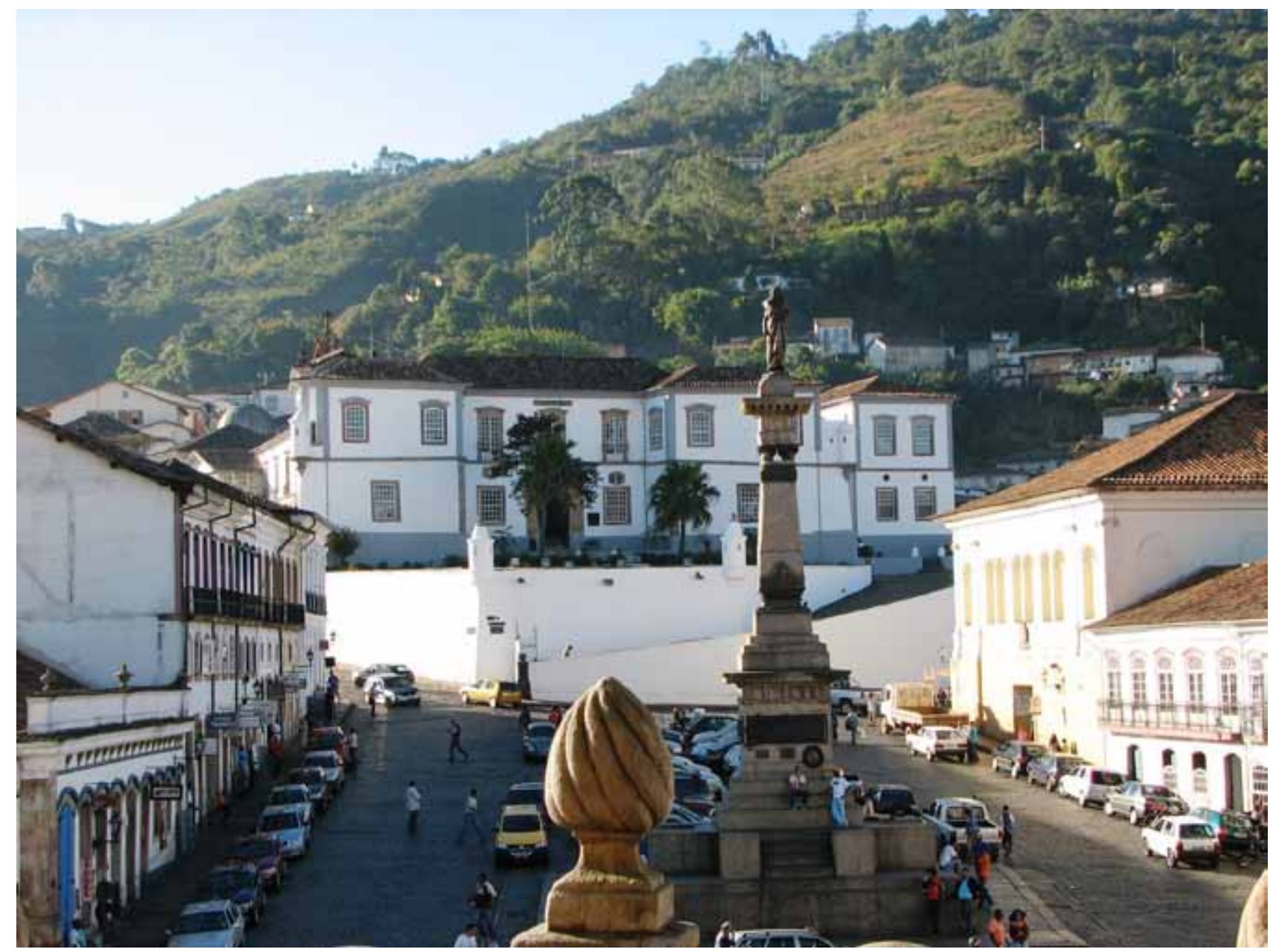

Figura 3: Palácio dos Governadores, Ouro Preto, abril de 2002. Fotografia e acervo do autor.

16. Antonio de Albuquerque Coelho de Carvalho nasceu em Lisboa em 1655 e faleceu em Luanda,Angola, em 1725. Foi capitão da Vila de Setúbal e Governador de Olivença servindo também em várias guerras e expulsões de invasores. Foi o responsável pelo "estabelecimento da ordem administrativa e judiciária metropolitana na região [de Minas] a partir de 1711". Cf. CODICE Costa Matoso (1999, v. 2, p. 32-33).

17. Cf. Manuel C. Teixeira e Margarida Valla (1999, p. 260). Segundo informações que me foram gentilmente oferecidas pelo historiador e jornalista Edgar Rodri- ser nomeado em 1709 governador e capitão-general da capitania de Minas Gerais e São Paulo, havia sido governador e capitão-mor do Grão-Pará ${ }^{16}$. Habilitado por esse cabedal, chegou a orientar, em 1688, a construção de uma fortificação - o Forte de Santo António do Macapá -, edificação adaptada sobre as ruínas do forte inglês de Cumaú, que representou justamente a "primeira ocupação efectiva por parte dos portugueses do sítio de Macapá"17. Muito provavelmente, portanto, Antonio de Albuquerque conhecera os tratados e os preceitos que, no final do século XVII, subsidiavam a formação dos oficiais e técnicos portugueses: o preceito regular que neles orientava rumo à adequação das edificações e povoações aos sítios e suas preexistências, pois inclusive ajustara o "novo" Forte de Santo Antônio às antigas ruínas do forte inglês; e certamente conhecia, em prática, as qualidades construtivas dos terrenos mais planos, porque o próprio governador lamentara em Vila Rica a falta de um "sítio" mais "acomodado". Nesse caso específico, o aspecto "acomodado" parece estar 


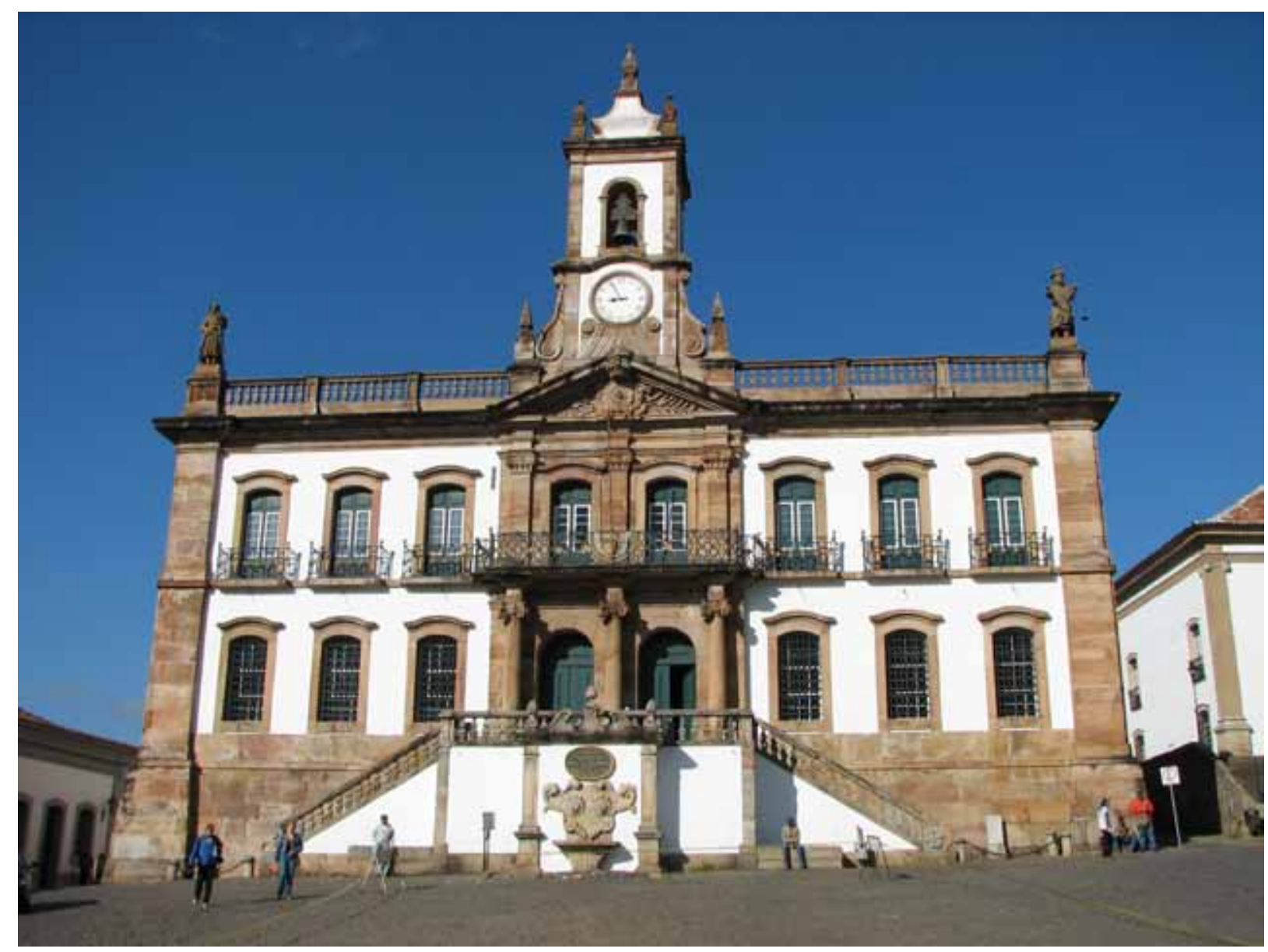

Figura 4: Casa de Câmara e Cadeia, atual Museu da Inconfidência, Praça Tiradentes, Ouro Preto, abril de 2002. Fotografia e acervo do autor.

diretamente relacionado às propriedades topográficas do sítio, muito embora sob esta qualificação já estivessem implícitas expectativas destinatárias, positivas ou negativas, quanto à comodidade oferecida pela povoação lem convênio com seu sítio) ao melhor proveito dos usos públicos e civis.

As condições "não muito acomodadas" do sítio foram um dos obstáculos para que Vila Rica, embora capital da capitania e nitidamente destacável em meados do século XVIII, não viesse a ser escolhida como sede do Bispado e elevada a categoria hierárquica de "cidade". Foi preterida em relação à Vila de Nossa Senhora do Carmo - a primeira criada em Minas Gerais -, cujas condições do sítio, embora também minerador, eram melhores se comparadas às de Vila Rica. Tanto o termo de ereção da Vila de Nossa Senhora do Carmo, em 8 de abril de 1711, quanto o de sua elevação a cidade, em 23 de abril de 1745, declaram essas qualidades mais apropriadas. Segundo esses documentos de ereção, Vila do Carmo havia sido implantada em "citio muito comodo"18 e gues, de Macapá, até 1976 existiam ruínas do Forte de Santo Antonio. O governador Arthur de Azevedo Henning, governando o estado do Amapá entre 1971 e 1975 , privatizou o local em nome da companhia de navegação Jonasa, que por sua vez repassou o terreno ao empresário Roberto Rodrigues. Este limpou completamente o terreno, inclusive as ruínas e antigas fundações do Forte. Restam, segundo Edgar Rodrigues, apenas relatos e algumas cartas que estão na 2. regional do IPHAN do Pará. Em contato com Mariana Sampaio, arquiteta dessa regional, acessamos um artigo - As Fortificações 
daAmazônia - publicado nos Annaes da Biliotheca e Ar chivo Público do Pará, em 1905, em que aparecem uma planta e um perfil bem precários do Forte de Camaú, ou de Santo Antonio do Macapá, como o denominou Antonio de Albuquerque. Cf. FORTIFICAÇÕES da Amazônia (1905, p. 241-244). Curioso notar que o forte foi batizado como Santo Antonio, nome de um santo homônimo ao governador: Anos mais tarde, em Vila do Carmo e Vila Rica, Antonio de Albuquerque, desta vez com o seu sobrenome, também teria querido denominá-las "Villa de Nossa Senhora do Carmo de Albuquerque" e "Vila Rica d'Albuquerque" -, o que não foi aceito pelo rei.

\section{Cf.APM SC 86,f. 33}

19. Cf. APM SC 06, f.14, 14v, 15.

\section{Cf.APM SC 86 ,f. 33}

21. Reza a carta régia que nomeou o governador: "Antonio de Albuquerque Coelho de Carvalho: Amigo, Eu El Rey vos envio muito saudar. Sendo Me presente hua consulta do Meu Conselho Ultramarino, arbitrios, e pareceres dos Ministros, por quem Mandei considerar os meios convenientes substabelecer em melhor forma o governo das Minas. Fui servido nomear-vos como por esta Nomeio por Governador de S.Paulo, e das Minas do Ouro de todos aquelles Districtos [...], e façaes $a$ vossa residencia em qualquer destas partes, que vos parecer mais conveniente ao Meu Serviço; pondo em execução que se fundem alguas povoações para que as pessoas que assistem nas Minas virão reguladas, e na Sobordinação da justiça [...] procureis estabelecer a forma com que se possão evitar os descaminhos, que se cometem no pagamento dos quintos do Ouro. E para este effeito vos Concedo toda a jurisdição necessaria "capaz"19, e sobretudo era "amaes antigua"20 vila de Minas Gerais. Na metade do século, Vila do Carmo se apresentaria, assim, adequadamente "adornada" de algumas intervenções urbanas "necessárias", mais decente para receber em seu sítio a catedral e tornar-se a sede do bispado na capitania.

Embora a criação de vilas fosse recomendada em sítios pouco distanciados "das ribeiras principais do ouro", como acontece exemplarmente em Vila Rica - o que frequentemente proporcionava esses sítios problemáticos-, poderia acontecer de se pretender mudar de sítio para que mais convenientemente se condicionasse a "nova povoação". Um pouco mais tarde, em 1713, na criação da Vila de São João del Rei, por exemplo, o então governador D. Bras Balthazar da Silveira, sucessor de Antonio de Albuquerque, resolveu "mudar" a nova povoação do lugar em que primeiro se instalaram os mineiros, desejando separá-la do terreno das lavras e orientar seu crescimento sobre um sítio "mais capaz e conveniente". Como declarado no Auto de levantamento da Villa, também os moradores aprovaram aumentar a povoação "na chapada do morro que fica da outra parte do córrego [do Lenheiro], para a parte da nascente do dito arraial, por ser o citio mais Capás e conveniente para se continuar a dita Villa". Todavia, a transferência da povoação não se deu tão facilmente. Somente a partir de 1740, aliviada a contenda pelos sítios e provavelmente decadentes as antigas lavras, implantaram-se construções de maior vulto naquele que era o local escolhido para acomodar a primeira vila implantada pelo governador D. Brás. Dentre elas, a destacável capela da Ordem Terceira de São Francisco de Assis (Figuras 5 e 6 ).

Voltemos a Ouro Preto. Doravante não restaria, senão, diante da resolução tomada pelo governador em "Junta geral", adaptar Vila Rica - a "nova povoação" - ao sítio escolhido - arraiais preexistentes e terrenos ainda desocupados, como o próprio morro de Santa Quitéria -, acomodando-the novas e necessárias estruturas - novos edifícios e arruamentos, a residência do próprio governador (ainda instalado, como cita o documento, em "casas de morada"), o quartel etc. É preciso destacar que alguns desses edifícios já haviam sido recomendados pelo próprio rei a Antonio de Albuquerque quando de sua nomeação, em 1709, oportunidade em que o orientou a "considerar os meios mais convenientes [para] substabelecer em melhor forma o governo das Minas"; a fazer residência do governador "em qualquer das partes, que vos parecer mais conveniente ao Meu Serviço"; a fundar povoações para que as pessoas viessem "reguladas e na sobordinaçaõ da justiça"; a "levantar Caza de fundição" a fim de se evitarem os "descaminhos" do ouro na cobrança dos quintos e "hum Regimento de Infantaria de Lotação de quatro centas, ate quinhentas Braças", e, ainda que pela presença "justificada" da força, conservar a "paz" na região21.

Entre a nomeação de Antonio de Albuquerque, em 1709, e a criação das primeiras vilas, em 1711, outro fato significativo comprova a prematura e devida atenção da coroa para com a fundação de novas povoações em Minas Gerais. Aos dez dias do mês de novembro de 1710, portanto aproximadamente 
cinco meses antes da ereção pioneira de Vila do Carmo, o governador Antonio de Albuquerque realizou uma grande "Junta Geral" destinada a, entre outros assuntos relativos à cobrança dos quintos, tratar justamente da implantação de vilas nos sítios que fossem considerados os "mais convenientes". A convocação da Junta estava orientada por Carta régia, e objetivava estabelecer a "melhor forma para a Conservação desta nova Conquista, considerando os meyos mais uteis para o Seu augmento [...] [e] Socego dos Povos [... $]^{\prime \prime 22}$. Oportuno ressaltar estas três qualidades frequentemente presentes nas disposições coloniais relativas tanto às conquistas quanto às povoações e seus moradores. São elas: a "conservação", o "aumento" e o "sossego" - três pilares de sustentação da acomodação e da permanência.

Logo após relatar - e vale ressaltar o termo utilizado pelo governador - que já havia "principiado na composiçaõ dos moradores de S. Paulo"23, o governador lançou aquele que deveria ser o primeiro assunto: justamente o "Lugar para que possaes levantar Caza de Fundição, onde se leve todo o Ouro em pó para ser fundido e marcado [...] Vos Ordeno levanteis logo hum Regimento de Infantaria de Lotação de quatro centas, ate quinhentas Braças. E por esta vos Concedo faculdade, por esta vez somente, para poderes nomear todos os Officiaes necessarios [...] este Regimento não he para os conquistar, porque estou certo na obediencia, que tem, e fidelidade que devem Guardar ao seu Principe, mas que he para os defender de violencias, e conservar em paz, e justiça, que he a primeira obrigação do Rey [...]".

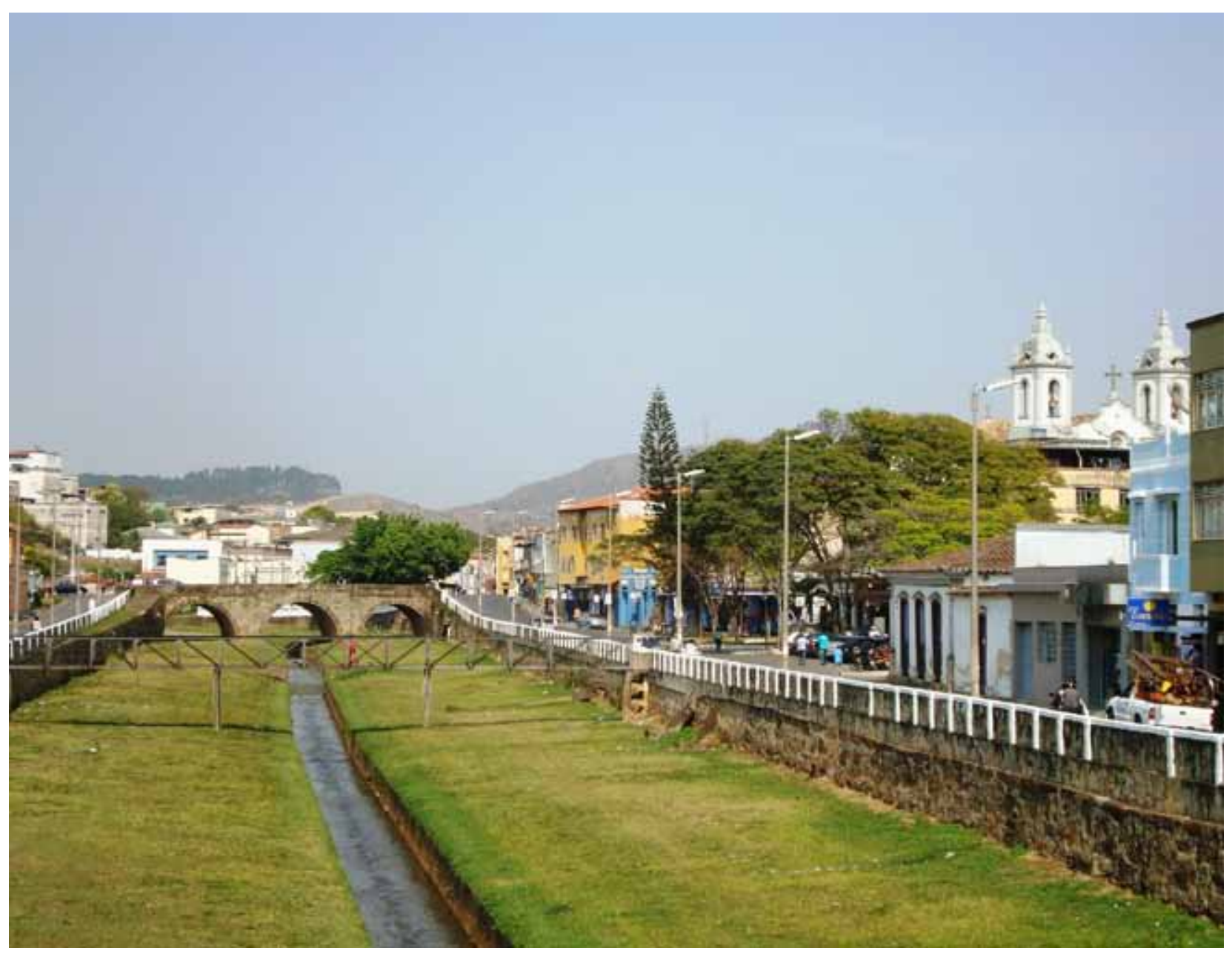

Figura 5: Vista de São João del Rei (Foto de Isabela Berg), abril de 2002. Fotografia de Isabela Berg. Acervo do autor.

Annals of Museu Paulista. v. 20. n.1. Jan.-Jun. 2012. 


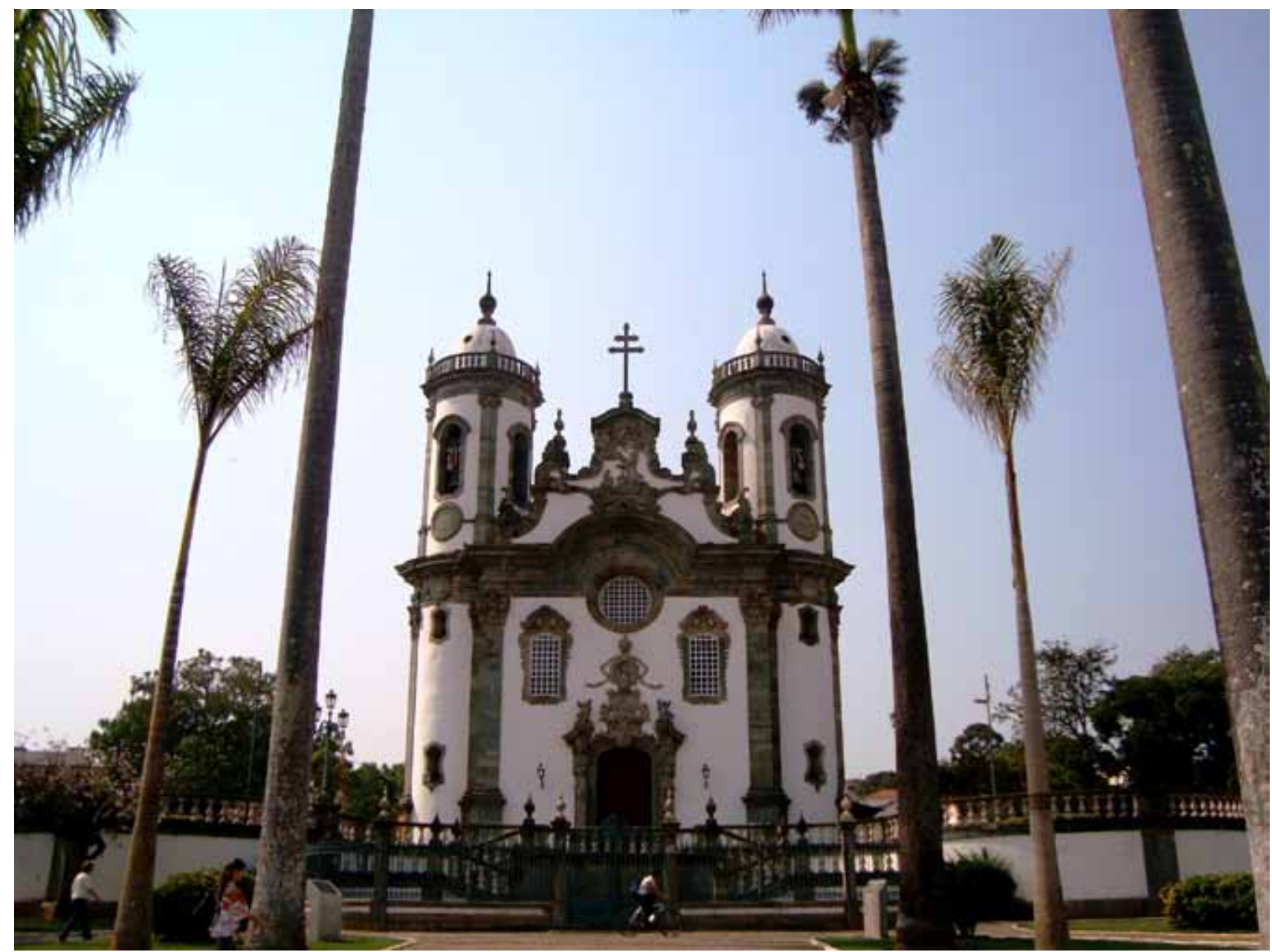

Figura 6: Capela da Ordem terceira de São Francisco de Assis, São João del Rei, abril de 2002. Fotografia de Isabela Berg. Acervo do autor.

APM SG Cx. 01, doc. 01 (doc. avulso), f. 1-2v (cópia); grifo nosso.

22. Cf. APM SC 06, f. 9, 9v. Participaram da junta representantes de praticamente todos as hierarquias administrativas, bem como dos moradores daqueles lugares onde - e não por acaso, nos próximos anos, entre $1711 \mathrm{e}$ 1718 - seriam fundadas as "novas povoações": "Prelados Eclesiásticos, vigarios da vara dos distritos do Rio das Velhas, Caeté, Sabará, Ouro Preto, e Ribeiraõ de N.S. $r^{\text {a }}$ do Carmo, e do Rio das Mortes, e de erigir villas, em que estes Povos vivessem Reglados, e experimentassem a Paz". E condicionava, assim, a eleição dos "sitios mais convenientes", adiantando que, para tanto, seria necessária a "ponderação" dos povos, mediada pelo "parecer" dos "assistentes" eleitos dentre os moradores. Após externar a necessidade de ouvi-los também com relação ao "meyo mais suave para a boa arrecadação dos quintos do ouro", concluiu que deveriam esses, os "assistentes", "ponderar com todo o Socego, e attençaõ pela Sua importancia" - do que dependiam mutuamente, imprescindível destacar, "a conveniencia, ou prejuizo, da Fazenda Real, e dos Povos". 
Antonio de Albuquerque abriu mão da comodidade do sítio por conciliar diretamente as conveniências externas, destinatárias, relativas declaradamente ao "comércio". Por sua vez, o "comércio", este foi fundamental para que Sylvio de Vasconcellos defendesse a hipótese de que não apenas a mineração havia sido responsável pela concentração dos assentamentos urbanos em Minas 24 . Vasconcellos estava por demais atento às hipóteses que the interessavam, e aparentemente não percebeu, nesse episódio de implantação da vila, as entrelinhas de um processo que abrangia a escolha do sítio, a destinação ética da povoação (consideradas as "conveniências" da metrópole e também dos "povos") e a consequente e posterior acomodação das estruturas urbanas circunstâncias frequentemente tratadas na formação doutrinária e prática dos técnicos, engenheiros e arquitetos responsáveis pela implantação de edifícios, fortificações, vilas e cidades no ultramar, fundamentadas, entre tantos preceitos, na consideração judiciosa e prudente do decoro.

Vasconcellos afirmou o desenvolvimento do comércio logo nos primeiros anos, dedicando-lhe bastante responsabilidade na sustentação das vilas mineradoras - locais de circulação de dinheiro, subsistência dos mineradores etc. A palavra "comércio" possuía, no princípio do século XVIII, outro sentido que não apenas o de transação econômica, bastante estimulante se considerarmos os aspectos que caracterizam a comunidade humana organizada em núcleos concentrados e a vida em sociedade. Recorramos a Bluteau: "Commércio" era um "Negocio de Mercancias, ou de dinheiro com mercadores", mas "Commércio" designava também a própria "Sociedade"; "communicaçaõ que huma pessoa tem com outra (Commercium, Consuetudo, inis)" 25 . No termo latino Consuetudo concentram-se os hábitos e costumes que acabam proporcionando o conjunto de valores (sobretudo se cotidianamente alimentados pela permanência) que conformam o éthos de determinada coletividade, alicerces a partir dos quais o decoro sustentava sua motivação ética. Ora, tanto o comércio "negócio de mercancias" quanto o comércio "social" estimulavam e dependiam de concentração urbana. Aquele referido no "Termo" deve tender mesmo para o "negócio de mercancias", hipótese reforçada pela obra de Antonil, Cultura e opulência do Brasil por suas drogas e Minas ${ }^{26}$. Exatamente coetânea do momento de ereção de Vila Rica, a obra do padre jesuíta exaltou o intenso comércio de mercadorias que se realizava nas Minas ainda na primeira década dos setecentos. A aceitação dessa hipótese não elimina, entretanto, a compreensão do "comércio" como mais um dos aspectos constituintes do hábito e dos costumes da comunidade mineradora que então esboçava sua formação, constituindo inclusive um fator decisivo - dependente e estimulador - para a concentração urbana. Ademais, é ainda o comércio "mercantil" um dos principais intensificadores do comércio "social". os capitães mores, e sargentos mores dellas, quardas mores, procuradores da Fazenda Real, e quatro Sogeitos de cada hum dos ditos destrictos, eleytos pelos moradores delles [...] em ordem a assistirem em nome dos Povos â dita Junta [...]". Ibidem.

23. Cf. APM SC 06, f. 9; grifo nosso. Em São Paulo,Antonio de Albuquerque realizou a junta correspondente ao tratamento desses temas quatro meses antes, em 7 de junho de 1710 , momento em que já se cogitava a elevação da então "vila" à condição de "cidade"; e a nomeação, "quando possível", de um bispo (criação de um bispado), pela falta de que padeciam "Suas ovelhas" sem visitas mais constantes daquele que se encontrava muito "distante", no Rio de Janeiro. Cf. APM SC 06, f. 3-5. São Paulo será "Cidade" ainda em 1711, mas sediará bispado apenas em 1745, mesmo ano em que Mariana foi criada com esse objetivo. Embora o bispado só se instale em São Paulo em 1745, o Rei já havia autorizado o governador Antonio de Albuquerque a instalá-lo tão logo fosse elevada a cidade, conforme se lê nesta Ordem régia datada de 16 de março de 1711:"em que Sua Magestade dá ao governador Albuquerque, que vendo sua carta de 12 de Outubro do anno passado, e as razoes, que dá para se permitir o titulo de Cidade á Villa de S. Paulo, e hum Bispo para a mesma, em razão de não poder o Rio de Janeiro providenciar de tão longe as muitas faltas, que padecem os Povos, e he de mandallo informar quantos vizinhos tem a Villa de S. Paulo, e quantas Villas, e Povoações há na sua Comarca deTerra para cima,e quantas ficão a baixo da Serra para o Mar pertencentes ao Bispado do Rio de Janeiro, e a distancia, que deste vai a $S$. Paulo, para se tomar nesta materia a resolução preciza [...]". Cf.APM SC 03, f. 2.

24. Baseada principalmente nas "pequenas monografias" 
de Waldemar de Almeida Barbosa,Cláudia Fonseca sustentou também a importância dos "movimentos agrícolas de população" como um dos fatores decisivos nos assentamentos humanos em Minas Cf. Cláudia Damasceno Fonseca (2001, p. 50)

25. Cf. Raphael Bluteau, s.v. COMMERCIO (1712, v. 2, p. 402)

26. Cf. André João Antonil (1963).

27.Ver Salomão de Vasconce$\operatorname{los}(1955)$

28. Ver Sylvio de Vasconcellos (1959).

29. Cf. José Joaquim do Couto (1905, p. 74); grifo nosso $\mathrm{O}$ trecho grifado na citação etá citado em Waldemar de Almeida Barbosa,, s. v. CATA Altas (1995, p. 120-121), do qual retrocedi ao original publicado na Revista.
Os primeiros aforamentos posteriores a 1712 confirmam o grande número de "vendas" e "lojas" existentes nos dois arraiais (num total de 51 em Pilar e 73 em Antonio Dias), onde também os moradores disponibilizavam publicamente seus ofícios: carpinteiros, ourives, pintores, sapateiros, ferreiros, seleiros, boticários, alfaiates, ferradores, cirurgiões, violeiros, barbeiros, oleiros, tabeliães etc ${ }^{27}$. Parece legítimo supor que o maior número de estabelecimentos comerciais em Antonio Dias também tenha colaborado na definição pela comunhão dos dois arraiais, se considerarmos que a ordem régia "determinava" Nossa Senhora do Pilar. Afinal, foi com base nessa comunhão que se localizou "o sítio de maiores conveniências que os povos tinham achado para o comércio", política e estrategicamente centralizado, anos depois, pela Praça Tiradentes, câmara e cadeia definitivas, e o palácio do governador. $\bigcirc$ engenhoso governador tinha consciência da importância de sua escolha urbanística, por assim dizer. Conveniar os dois arraiais em uma só vila, equilibrados pelo Monte de Santa Quitéria, que futuramente receberia a Praça Tiradentes e seus edifícios públicos, acabou determinando Vila Rica como uma das povoações mais eloqüentes do universo luso-brasileiro. Se o governador optasse apenas pelo Arraial de Nossa Senhora do Pilar, como determinava a ordem régia, é bastante verossímil supor que o corpo urbano da povoação tivesse outro desenvolvimento e caráter.

O comércio foi também responsável pelos inúmeros pousos nos percursos dos caminhos que cortavam as minas. Aventada no estudo de Vila Rica, Sylvio estendeu às demais vilas e arraiais mineiros a importância dos caminhos em suas formações ${ }^{28}$. As estradas que ligavam as povoações as teriam conformado predominantemente longilíneas e lineares, obviamente concentradas por patrimônios religiosos e principalmente pelo comércio, sempre conveniente se encontrado nos "pousos" pelos caminhos. Mas Sylvio de Vasconcellos não foi o primeiro a levantar esta hipótese das estradas e caminhos conformadores das povoações mineiras. Ainda na virada do século XVIII, entre 1800 e 1801, José Joaquim do Couto, partindo do Tejuco (atual Diamantina), realizou expedição por várias vilas e arraiais mineiros, e escreveu sua Memória sobre a Capitania de Minas Gerais. Quando de passagem pelo arraial de Catas Altas do Mato Dentro, já influenciado pela visão depreciativa que acompanhou boa parte dos viajantes oitocentistas, descreveu:

Catas Altas é um arraial tão grande como o de Santa Bárbara, porém muito mais decadente. As suas casas são mais ordinarias, quasi todas baixas e de traça antiga [!], muitas dellas meias cahidas, e outras totalmente. A povoação fica na maior parte ao comprido, e se alonga pela estrada, vício geral de quasi todos os arraiaes de Minas, que foram todos formados sem gosto, e como para pouco tempo à beira dos rios que davam o ouro ou pela estrada ao comprido à maneira de feira. A serra fica imminente por um lado sobre o mesmo arraial. Talhada quasi a prumo, altissima; e pelo outro lado circulam rasas campinas ${ }^{29}$ (Figuras 7 e 8). 
Embora Vasconcellos não tenha feito referência a essa passagem de José do Couto, citou sua Memória, ao acrescentar um dado para conferir a população de Vila Rica. É muito provável, pois, que a constatação de José Joaquim do Couto, ainda na virada dos oitocentos, tenha induzido, cento e cinquenta anos depois, as hipóteses de Sylvio de Vasconcellos ou nelas vigorado. Aceitar o sítio dos arraiais significou aceitar, portanto, além de aspectos do modo

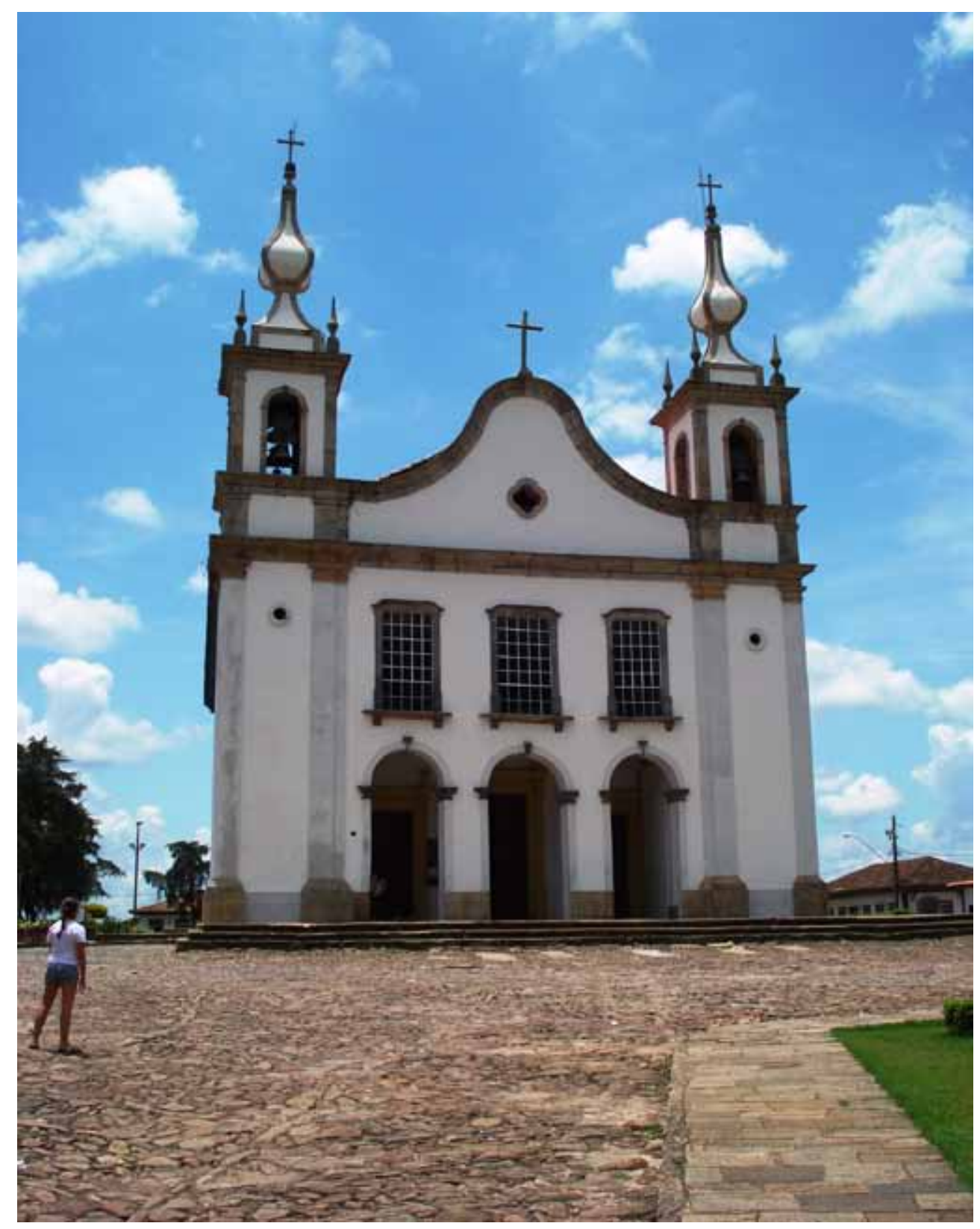

Figura 7: Praça da Matriz de Nossa Senhora da Conceição, Catas Altas, abril de 2002. Fotografia e acervo do autor. 


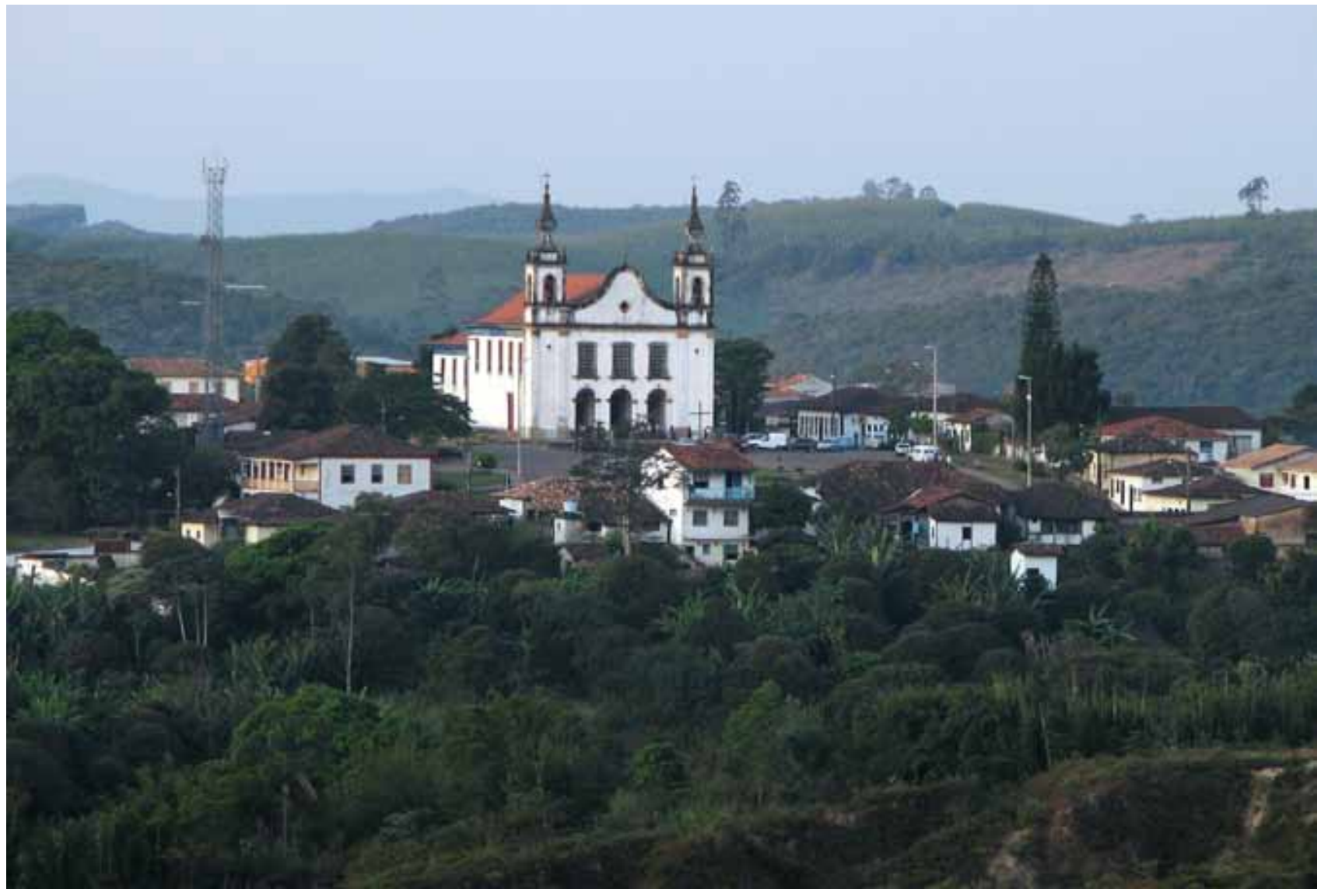

Figura 8: Praça da Matriz de Nossa Senhora da Conceição e Serra do Caraça, Catas Altas, abril de 2002. Fotografia e acervo do autor.

30. Apesar de Sylvio ter consagrado o termo "espontaneidade" para qualificar e definir as povoações mineiras, seu pai, Salomão de Vasconcelos, já o havia utilizado anteriormente, justamente para especificar as primeiras ocupações realizadas pelos mineradores. Concluindo pesquisa e citação dos aforamentos concedidos entre 1712 e 1721 , declarou que a maior parte destes aforamentos "teriam vindo já do aposseamento espontâneo ligado ao descobrimento". Salomão concluiu também que, em 1721, Vila Rica já estava aberta em sua configuração geral apresentada ainda na primeira metade do século XX. Cf. Salomão de Vasconcelos (1941, p. 257). de vida que se pretendia manter - ainda que adiante "regulado" e "sujeito às leis da justiça" -, também as primeiras ocupações ditas "espontâneas" 30 já realizadas pelos moradores, igualmente sujeitas, a partir de então, a regulações de ordem e requisições de decência. Modo de vida e acomodação urbana, não por acaso referidos aqui conjuntamente, passaram a orientar-se por regulações proporcionadas à dignidade hierárquica da povoação, motivadas pelas conveniências metropolitanas e temperadas pelas conveniências populares. A partir de então, uma nova disposição de permanência, por assim dizer oficialmente inventada e instaurada, deveria levar a um gradativo incremento das primeiras construções existentes - as "habitaçõesinhas provisórias" -, exigindo, além de uma necessária adequação de estruturas construídas, o "aumento" da dignidade aparente das construções e do próprio caráter urbano das povoações, objetivo presente durante toda a primeira metade do século XVIII. Observa-se, em vários documentos e contextos, um duplo sentido para o termo "aumento", ambos diretamente relacionados ao estudo das intervenções urbanas setecentistas: 
"aumento" como incremento quantitativo - expansão física -, e também qualitativo - incremento de dignidade 31 .

Compreendo, pois, as implantações das primeiras vilas como o lançamento da gradativa constituição de um decoro das povoações, processo que acompanhou suas próprias constituições físicas. Esse processo deveria se manifestar tanto no aspecto exterior (aparência) apresentado pelas edificações e estruturas urbanas, quanto na comodidade por elas oferecida. Ao mesmo tempo em que gradativamente se foi constituindo esse decoro das povoações, as comunidades locais foram se consolidando, concentradas em entidades religiosas e assistenciais - as irmandades -, outro importante aspecto do modo de vida das povoações mineiras. Intensificaram-se as ereções de capelas a fim de abrigar com mais "comodidade"32 seus "exercícios", acompanhadas por requisições de condignidade, "decência", "melhor vista" 33 e "ornato". Tais requisições aparecem, sobretudo, nas petições redigidas para o licenciamento das construções, quando se procurava justificá-las com os argumentos proselitistas de se "persuadirem" outros irmãos e, sobretudo, de se "aumentar" a Ordem. As mesmas requisições de decência e ornato eram exigidas também nas celebrações e nas festas realizadas na própria povoação: ruas, largos e adros anteparados cenograficamente pelos frontispícios das numerosas capelas (Figura 9).

Estudiosos exaltaram a grande empresa construtiva que se deu entre os anos de 1740 e 1760 - comumente chamado "período áureo da Vila" -, indicado pelas numerosas construções de pontes, chafarizes e capelas. É importante salientar, contudo, que o movimento de "reedificação", reforma e ereção de novas construções é oficialmente requerido e observável, ainda que se efetive lentamente, desde a década de 1711, logo após a implantação da vila e da câmara, com significativas intervenções ainda nas primeiras décadas dos setecentos. Indicam-no as tentativas de se lançarem "em praça" construções como a Casa de Câmara e o quartel, e os primeiros aforamentos a partir de 1712, quando foram feitas referências explícitas - aparentemente condicionando a própria concessão da terra (em média duas a quatro braças: 4,40 m a 8,80 m) - à substituição de "palha" por "telha", ao "alargamento" das casas, e, em alguns casos, à própria "reedificação"34. Novas ou em reedificação aos primeiros ranchos, as casas doravante construídas pretender-se-iam, salvo raras exceções ${ }^{35}$, com melhores materiais; avançando pelo século com aparência e solidez mais dignas e melhor alinhadas, dentro do possível, diante do "endireitamento" das ruas existentes e dos novos arruamentos abertos.

\section{A "acomodação" dos moradores}

Outro argumento colabora com essa hipótese do lançamento de um movimento regulador não apenas fiscal, mas, por assim dizer, também urbanístico a partir de 1711 . Reside na presença mais constante, em Minas Gerais, de
31. Bluteau apresenta para o termo "Augmento" a noção geral de "acrescentamento". Aplicado a coisas contáveis, quando se refere a um incremento objetivo, mas também a coisas incontáveis, quando o objeto do "augmento" é uma qualidade. Exemplos: 1.o (incremento quantitativo): "Com a virtude do Sol tudo floresce, \& tudo se augmenta na sua especie"; 2 .o (incremento qualitativo): "Este mal da Republica, que com o castigo deste homem, teve alguma diminuição, se augmentará, se aos outros se perdoar a vida". Cf. Raphael Bluteau, s.v.augmento (1712, v. 1, p. 670).

32. Em carta ao seu procurador, de 13 de abril de 1755 , os irmãos da Ordem Terceira de São Francisco de Assis de Vila Rica justificavam assim a ereção de sua capela: "[...] que os terceiros desta Venerável Ordem, instituída no ano de mil e setecentos e quarenta e seis, [...], nesta Matriz de Nossa Senhora da Conceição de Vila Rica, Bispado da cidade de Mariana, se acham oprimidos pelo grande número de mais de mil irmãos para nela poderem exercer seus atos, conforme lhe determinam seus Estatutos e Regra, pela pouca comodidade que para isso bá na sobredita Matriz $\mathrm{e}$ muito menos para nela se recolherem todos os paramentos de que a dita Ordem se acha enriquecida, por êstes se acharem dispersos por casas particulares dos irmãos, lugares pouco decentes para o seu culto [...]". Apud Raimundo Trindade (1951, p. 254-255); grifo nosso.

33. Ver Rodrigo Almeida Bastos (2010).

34. Para "transformar o seu rancho de palha em hum de telhas"; para "reedificação de hum rancho"; "braça e meya de terras para alargar huas cazas em vive [...]". Apud Salomão de Vasconcelos (1941, p. 244 et seq.) 


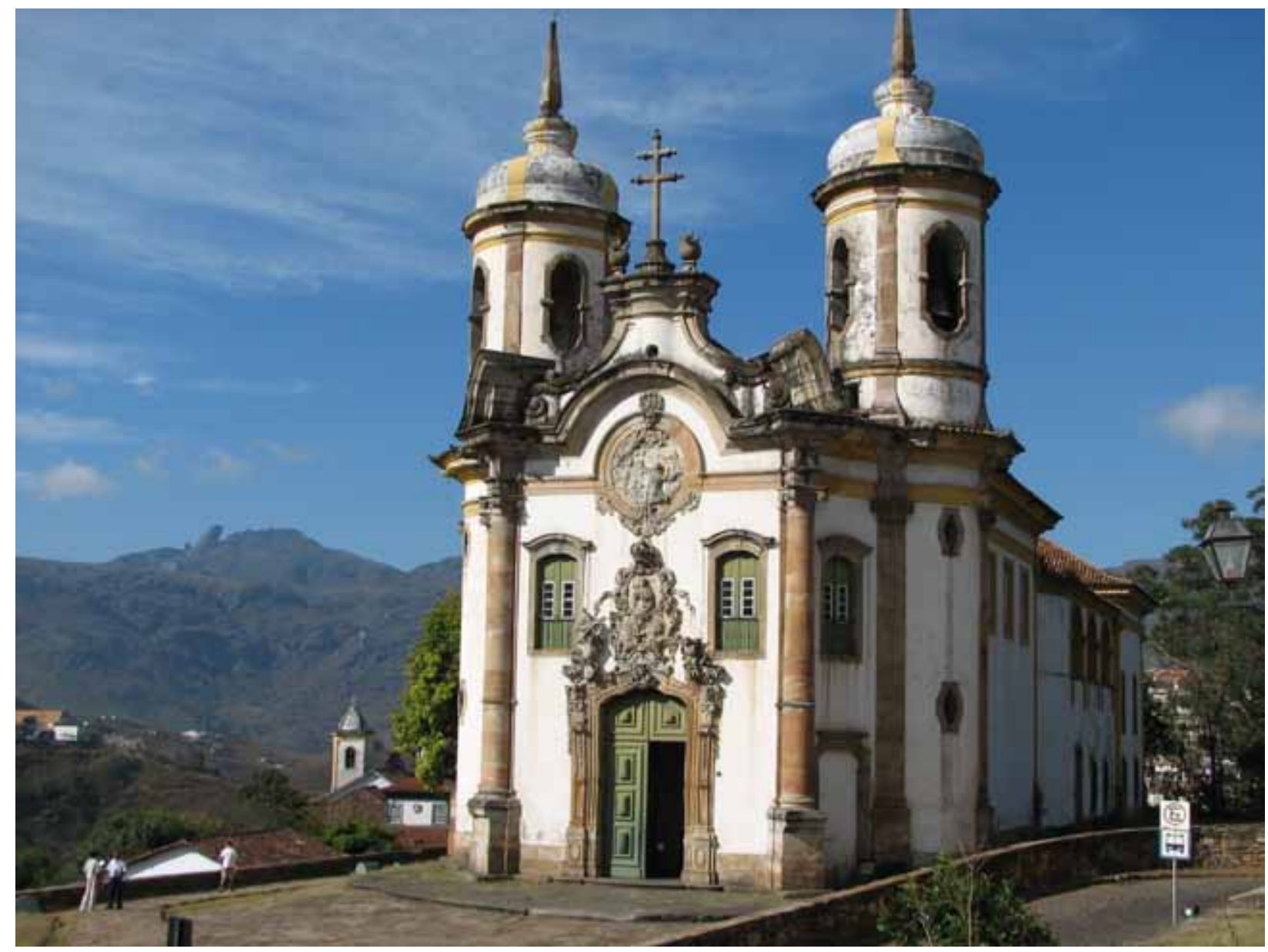

Figura 9: Vista da Capela da Ordem terceira de São Francisco de Assis e Serra do Ouro Itacolomy, Ouro Preto, abril de 2002. otografia e acervo do autor.

35. Há um aforamento, posterior a 1718 , licenciando Marcos Pinheiro a "levantar hum rancho de palha na travessa que vae para o Semiterio"; apud Salomão de Vasconcelos (1941, p. 255).

36. Cf.APM SC 09, f. 20v-22.

37. Cf. Vicente Soares (1972, p. 72). oficiais, técnicos e engenheiros militares enviados pela coroa. E suas atuações não se restringiam aos núcleos das vilas elevadas, operando também nos arraiais de seus termos e nos "novos descobrimentos"; superintendendo na administração e na "repartição" de datas de terra, e, sobretudo, numa requerida "acomodação" dos moradores. São as ordens que literalmente encontramos na Instrucçaõ ${ }^{36}$ expedida pelo governador-general D. Bras Balthazar da Silveira ao sargento-mor e engenheiro militar Pedro Gomes Chaves, enviado a Pitangui - então apenas um "novo descobrimento" - em abril de 1714. As notícias que chegavam ao governador declaravam "algumas inquietações" decorrentes de desacordos na repartição das lavras. Era preciso "remediá-las", razão pela qual o engenheiro foi enviado. Escrevendo a História de Pitangui, monsenhor Vicente Soares relatou que, em 1713, os mineiros trabalhavam onde queriam, sem qualquer repartição oficial, e que a povoação só seria elevada à condição de vila em $1715^{37}$. Pedro Gomes Chaves foi enviado de Portugal para a colônia em 1709. Excetuando sua 
provável participação no risco para a lgreja Matriz de Nossa Senhora do Pilar de Ouro Preto ${ }^{38}$, o engenheiro militar é personagem pouco tratado pela historiografia, sobretudo se considerarmos sua presença em momento tão decisivo para a futura constituição dos conjuntos arquitetônicos e urbanos na capitania de Minas Gerais. Segundo o Dicionário, de Francisco Marques de Sousa Viterbo, o Conselho Ultramarino, em consulta de 11 de junho do mesmo ano, propunha-o em "primeiro logar" para o posto de engenheiro na praça da Bahia, obrigando-o não apenas a "ensinar na Aulla publica aos que quizerem aprender", como também servir "a toda parte onde for necessario". E ainda the acrescentava outros méritos, em comparação a outros engenheiros que igualmente deixavam a "Aulla" (em Portugal) e seguiam para as "conquistas", sem a "experiência" e a "capacidade" por ele já demonstradas:

Pareceo ao Conselho votar em primeiro lugar para o posto de engenheiro da dita praça [da Bahia] em Pedro Gomes Chaves, que sobre concorrer na sua pessoa haver seruido de soldado por espaço de sinco annos, embarcandose em algúas armadas, se mostra acharse nas prouincias de Alemtejo, Beira e Traz os Montes na mayor parte das ocaziões da guerra prezente, ocupando o posto de capitão engenheiro com grande aseitação dos generaes, e de ter boa noticia da sua capacidade e prestimo, com declaração que se the deve passar patente de sargento mor com trinta mil reis de soldo por mez, pois aos que saiem da Aulla, que vão para as conquistas, se the dão vinte e sinco mil reis por mez, sem terem a experiencia e graduação do supplicante, e nesta differença se fazer merecedor de algúa ventagem mais, impondoselhe a clausula de que não só será obrigado a ensinar na Aulla publica aos que quizerem aprender, mas que hira a toda a parte onde for necessario ${ }^{39}$.

Ainda que destinado à Bahia, já no ano de 1709 Pedro Gomes estaria no Rio de Janeiro, ensinando na Aula desta praça; e pouco mais tarde, em Minas Gerais, pelo menos a partir de 1711, data mais prematura de documentos que encontrei indicando sua presença. É realmente significativa a presença do engenheiro Pedro Gomes Chaves em Minas Gerais no exato ano em que se implantaram as primeiras vilas, embora seja possível que tenha chegado antes. A Instrucçaõ a Pedro Gomes Chaves para Pitangui data de 8 de abril de 1714. Foi redigida em sete parágrafos numerados, com os quais o governador confiava que o engenheiro, com sua "grande capacidade, e prudencia", iria a Pitangui "acomodar aquelles moradores, evitando todas as inquietações que posaõ alterar o Sosego de que nesesitaõ para o Seu aumento, e consequentem. te de todo este estado pellas utilidades que the resultaraõ ${ }^{\prime 40}$. Antes da Instrucçaõ, - mesmo códice possui várias cartas (todas datadas em 5 de abril de 1714) expedidas pelo governador D. Brás a moradores e oficiais de Pitangui, todas elas nomeadas. Uma delas, a Bartolomeu Bueno da Silva - o "segundo Anhaguera" -, na oportunidade capitão-mor em Pitangui e que viria, pouco mais tarde, a descobrir novas minas na região de Goiás ${ }^{41}$. $\bigcirc$ governador ressaltou nessas cartas a "grande prudência, e Capasidade" do engenheiro, com que todos ficarão "muy satisfeytos"42. Era preciso observar o Regimento das datas, aí resumido a partir do segundo parágrafo. Primeiro a data de El Rey, "na parte que
38. A notícia chegou até nós por Rodrigo Brêtas, biógrafo do Aleijadinho, ao citar o Registro de Fatos notáveis redigido em 1790 pelo 2 . vereador da Câmara de Mariana, o Capitão Joaquim José da Silva:"Este templo [matriz de Ouro Preto], talvez desenbado pelo sargento-mor engenbeiro Pedro Gomes, foi construído e adornado interiormente por Antônio Francisco Pombal com grandes colunas da ordem coríntia"; cf. Rodrigo Brêtas (1998, v. 3 -4,p.993-996); grifo nosso. O interior do templo, arrematado mesmo por Pombal, teve risco do então muito pouco citado Antônio da Silva. A capela-mor da matriz foi objeto de um "novo risco", dado a ela em 1741 pelo sargento-mor e engenheiro José Fernandes Pinto Alpoim, que também lhe acrescentou um zimbório,o único do tipo construído em Minas no século XVIII.A história inédita destas fábricas se encontra em Rodrigo Almeida Bastos (2009, p. 113-136)

39. Francisco de Sousa Viterbo, s. v. Chaves, Pedro GoMES (1922, v. 1, p. 210); grifo nosso.

40. Cf.APM SC 09, f. 20v; grifo nosso.

41. Cf. Vicente Soares (1972, p. 79). Segundo monsenhor Vicente, Bartolomeu Bueno não participou das rebeliões e inquietações de Pitangui por já estar preparando a expedição a Goiás, donde retornou em 1725 com a novidade do descobrimento. $\mathrm{O}$ próprio governador D. Brás, condicionado pela confirmação de os povos estarem bem repartidos e "acomodados", recomendou que se procurassem fazer "novos descubrimentos com os quais naõ So Se interessaraõ [os lavradores] mas a fazenda de S. Mag.de a quem darei Conta do que vosmecês obrarem nestas expedições [...] Vila de N. Sr. ${ }^{\text {a do Carmo }}$ 7 de julho de 1714 ". Cf.APM SC 09, f. 30.

42. Cf.APM SC 09, f. 18v, 19 $19 \mathrm{v}$. 

nosso.

46. Cf. APM SC 09, f. $21 \mathrm{v}$. Além da Instrucçã̃, carta a Pedro Gomes ordenava-lhe procedimentos relativos à cobrança dos quintos daquele ano. Devia informar aos moradores que, divididas às comarcas, tocava à povoação de Pitangui "hua arroba de ouro a qual he precizo, que os Seos moradores Satisfaçaõ com a mayor brevidade". Cf. APM SC 09 f. 22 parecer mais Rica, da qual tomara[á] conta o procurador da Faz.d. a para dispor dela na forma do Regimento"; depois dela, a dos governadores, "e depois se seguiraõ os descubridores observandoçe nas mais o que dispom [dispõe] o Regimento". O governador ainda estabeleceu, em nome do rei, uma data excepcional, destinada a prover e a sustentar "as obras publicas da cidade de S. Paulo cuja Camera Se acha[va] com poucos meyos [... $]^{\prime 43}$. A Casa de Câmara e Cadeia da Cidade de São Paulo estava, segundo declaração dos próprios camaristas e moradores, em condições indecorosas - literalmente "miserável" -, levando o governador a justificar - em nome do rei - a destinação da data ao denunciar o despropósito de se manter nesta situação a Câmara de uma cidade que não era senão a "capital de todo este estado" 44 . Em outro códice do Arquivo Público Mineiro, encontrei o documento em que D. Brás reconheceu a condição indigna da edificação "tão conveniente ao [bem] comum", quando resolveu deferir à solicitação, a fim de se "reparar" a edificação com mais "largueza" e "capacidade":

A Camara e Nobreza desta cidade me Reprezenta tão o mizeravel estado em que Seachavaõ a caza dacamara, e acadea della, e que necessitavaõ de obras asim para SeRepararem, como para ficarem com mais Largueza e capaçidade, e naõ havendo por ora donde Sepudeçe tirar o neçessario para esta obra, me Resolvo adar em nome de Vmag.de A mesma Camara huma data no Novo descubrimento para com o procedido do Seu Rendimento Se fazer esta obra declarandolhe porem quedella ham de pagar os quintoz aVMag. de que emtendo naõ desaprovarâ esta minha detreminaçaõ por Seencaminhar ao Reparo dehuma obra publica, e taõ conviniente ao [bem] Cumum [...] S. Paulo 20 deSetembro de 1713. D. Bras Balthazar da Silveira ${ }^{45}$.

Voltando à estada de Pedro Chaves em Pitangui, na Instrucçaõ o governador ainda exigiu ao engenheiro uma série de procedimentos. Dentre eles, remeter ao governador uma lista com "o numero de gente que se acha nessa parage [...] com a maior clareza", e orientar os moradores a solicitarem carta de sesmaria para as terras que quiserem ocupar ${ }^{46}$. Pedro Gomes Chaves realmente foi a Pitangui, é o que comprova uma carta do governador em 7 de julho de 1714, reclamando-the das informações que the havia solicitado na Instrucçaõ, e que certamente o engenheiro não enviara. $\bigcirc$ teor da carta insinua a severidade das ordens e a rigorosa expectativa de seus cumprimentos:

Estranho muito avm.e [a vosmecê] naõ mehaver dado conta assim da Sua chegada aessa parage como da forma em que achou os moradores della poiz bem sabe $\mathrm{vm}^{\prime}$ que me devia dar logo conta de todo o Referido histo sefaz mais Reparavel em vm'que mostra dezejar fazer aSua obrigaçaõ [...] cuide mais nella [?] porqueSentirei perder oConSeito [Conceito!] que athe agora tive de $\mathrm{vm}^{\prime}$. E aqui tenho noticia que a Repartiçaõ do novo descubrimento Se fes esse foi Segundo o disposto no capítulo quinto do Regimento de que Remeto acopia esta muy bem feita, mas nocazo deSe haver alterado alguma couza comoSuponho, vm' mandarâ Lansar hum Bando da minha parte pera que todoz os que Seacharem Lavrando no novo descubrimento dentro devinte ecoatro horas Se Retirem delle com osSeus escravoz, e Retira- 
doz que forem todoz hirâ vm' com o goarda mor Fran.co Jorge fazer Repartiçaõ do descubrimento na forma do dito Capítulo quinto tirando primeiro a data de S. Mag.de digo [!] do descubridor, a de S. Mag.de, a minha, outra ao mesmo descubridor como Labrador, as quaes todas haõ de Ser de trinta brassas, e no que Respeita a dos mineiroz observarâ o mesmo Capitullo atendendo aos Numero de escravos que tiverem [...] Vm' me Responderâ Logo que asim obrar [...] Vila de N. Sr.a do Carmo, 7, junho de $1714^{47}$.

A "acomodação" requerida pelo governador D. Brás ao engenheiro Pedro Gomes Chaves em Pitangui aponta, em vários pontos da Instrucçaõ, para uma aquietação das pessoas, entre si e diante das ordens e regulações da coroa - estratégia necessária porque também mantenedora da concórdia e da coesão entre as partes do reino. O governador afirmava ser a "acomodação" imprescindivel ao "sossego" e "aumento" dos moradores e, "consequentemente, de todo este estado, pelas utilidades que the resultarão"48.

Na tentativa de se estabelecer essa acomodação necessariamente política, acompanhavam-na, precisamente, disposições consequentes ao efetivo assentamento humano sobre as concessões de terra a serem "repartidas" - uma acomodação, pois, simultaneamente política e fundiária (resguardando-se os riscos de anacronismo ao me valer do termol tão conveniente à coroa e aos costumes reconhecidos e internalizados pelos moradores, delineadora de ocupações e de estruturas construídas. Quando o governador se referiu a uma "acomodação dos moradores", seu objetivo era, em primeiro lugar, estabelecer o "sossego", dirimindo as contendas pelas porções de terra sobre as quais se lavraria o ouro e, inevitavelmente, assentar-se-iam ranchos ou casas.

Analisando as estruturas que determinavam as relações entre "atores coloniais" e "atores metropolitanos" em Minas Gerais, Carla Anastasia e Flávio da Silva observaram o quanto o "pacto colonial" acordado na capitania foi mais complexo do que nas áreas agroexportadoras ${ }^{49}$. $\bigcirc$ estabelecimento de uma "ordem pública" era imprescindível, para a qual contribuiu sensivelmente a organização administrativa e urbana inaugurada em 1711 . Pertinente, então, ao desenvolvimento de qualquer temática investigativa, uma "grande questão" que se coloca aos estudiosos do século XVIII em Minas é, segundo os supracitados, compreender o modo de operação das estratégias de controle político implantadas na capitania. Quanto ao problema de implantação de povoações, essa questão é realmente fundamental, porque a ordem exercida não era senão manifesta e representada justamente no "lugar" onde os colonos se "acomodavam", trabalhavam e habitavam. Assim, a compreensão das povoações e sua arquitetura não pode prescindir da compreensão das circunstâncias e estruturas políticas, para as quais a consideração ético-retórica do decoro contribui, mas também as problematiza.

Aqui, a noção de "acomodação" impõe algumas instigações. Se, diante da doutrina do decoro, a acomodação pode ser definida como o arranjo adequado dos elementos e estruturas entre si e em relação ao todo que compõem, no contexto mineiro setecentista, o termo "acomodação" - recorrente nos
47. Cf.APM SC 09, f. 26, 26v. O governador corrigiu o lapso presente na Instruç̧ã reconhecendo a primeira lavra como sendo a do descobridor, depois a de Sua Majestade.

48. Cf.APM SC 09, f. $20 \mathrm{v}-22$.

49. Cf. Carla Maria Junho Anastasia e Flávio Marcus da Silva (2001, p. 307-332). 
50. Idem, p. 315.

51. Deve-se entender por "público", nesse momento, não o espaço da livre manifestação individual ou de grupos, que é uma noção contemporânea, mas o espaço da manifestação do "bem comum" - representação da concórdia e da paz do reino, necessidades das quais eram conscientes as partes que se alienavam do poder em subordinação ao rei. Cf. João Adolfo Hansen (2001, p. 180-189).

52. São João del Rei acabou se implantando em terreno mais cômodo. Os moradores e camaristas, dentro do jogo político inerente à disputa entre as povoações pelas melhores regalias, títulos e direitos, solicitaram, em 1749 , o título de cidade - como Mariana, e a despeito de não possuir bispado -, confiando em suas ruas mais "regulares" e edifícios "honrosos"; apud Cláudia Damasceno Fonseca. (2001, p. 346-347). documentos - possui ainda significados específicos. Segundo aqueles autores, a "acomodação" consistia em uma "situação de resolução temporária", na qual interesses metropolitanos e coloniais se apresentassem equilibrados - por um lado, à necessária regulação ordenadora metropolitana e, por outro, aos costumes, hábitos e privilégios internalizados e reconhecidos pelos moradores - e mutuamente satisfeitos. O respeito a esses costumes condicionava a conformação das chamadas "formas acomodativas" - modos de interação entre dominantes e dominados. E facultava a estes, inclusive, o estabelecimento de limites à metrópole no exercício do poder. Grande parte dos "conflitos" deflagrados em Minas foi motivada não tanto pelo abuso desse exercício, quanto pelo rompimento de "procedimentos costumeiros" que os colonos consideravam "justos" e "comedidos" 50 , bem como pela ameaça a privilégios e hábitos reconhecidos como necessários pelos colonos e a respeito dos quais o rei e seus conselhos não eram ignorantes.

A povoação era uma estrutura parcelar fundamental, componente do corpo político do reino, lugar por excelência da ação e da representação da ordem pública ${ }^{51}$ estabelecida. As regulações que orientavam prudentemente as "formas acomodativas" do pacto de sujeição deveriam reger também, pois, a prudente implantação das povoações, assim como a acomodação dos povos e, consequentemente, a acomodação das estruturas construídas. E era aí que o decoro ético-político deveria conciliar-se com o decoro artístico, procurando conformar o saber agir ao saber fazer - arte político-poética coerente com o regime retórico português nos séculos XVII e XVIII. A "ordem" metropolitana e os "costumes" consideráveis dos povos compunham, então, por assim dizer, dois polos de orientação e regência, dentro dos quais oscilavam as ações e as resoluções políticas, diretamente constitutivas da res publica. A integridade e a conservação das partes (físicas, aparentes) do "corpo" do reino representavam, adequada e proporcionalmente, a integridade e a conservação do próprio regime político. Ouso aventar que também deve ter sido por isso que, em Minas Gerais, além da natureza e topografia particulares - provavelmente mais do que em outras regiões da colônia -, a regularidade construída (manifestação persuasiva e significativa da ordem e do poder) foi aquela "regularidade geométrica possível", porquanto delicadamente temperada pelos costumes coloniais a serem mantidos. Um exemplo vigoroso disto é o próprio caso de Vila Rica, onde foi decisiva a manutenção do "sítio de maiores conveniências que os povos tinham achado para o comércio" - um dos aspectos do modo de vida que se pretendeu resguardar aos colonos -, onde a regularidade geométrica não restava senão condicionada, ou mesmo limitada, às incomodidades do sítio. Foi também em consideração aos costumes que os moradores de São João del Rei resistiram a mudar de sítio quando da elevação da vila por D. Brás em 1713. A despeito da promissora comodidade e da melhor regularidade (geométrica) que se podia esperar do novo sítio proposto, os lavradores estavam habitualmente "acomodados", desde os primeiros assentamentos, sobre terrenos bem próximos às lavras, costume que os permitia guardarem-nas mais de perto ${ }^{52}$. 
Termos como "acomodação", "conveniência", "formosura", "asseio", "capacidade", "aparência" etc. apresentam-se frequentemente nos documentos relativos à capitania de Minas. Não fosse a consciência de seus conteúdos éticoretóricos no século XVIII, confirmados pelas circunstâncias e considerações em que operaram, poderiam restar encobertas possibilidades interpretativas muito interessantes. Tais interpretações permitem retroceder à gênese das doutrinas da arte e da arquitetura - conservadas pela longa duração da retórica latina de que se serviu o universo luso-brasileiro -, proporcionando desenvolvimentos importantes à compreensão da formação e do desenvolvimento dos conjuntos urbanos coloniais.

Além da "repartição" de datas e da "acomodação" dos moradores, Pedro Gomes Chaves obrou em outras proporções - característica comum das diligências prestadas pelos engenheiros militares enviados para as conquistas. A necessidade de "mapear-se" o território, por exemplo, era melhor desenvolvida por eles, habilitados por procedimentos cada vez mais eficientes, recebidos nas "aulas" da metrópole e da própria colônia. Em 6 de abril de 1714, Pedro Gomes Chaves e o capitão-general Pedro Frazão de Brito estavam em Vila do Carmo para acompanhar e assistir a sessão de repartição das comarcas da capitania. Assistiriam-na para dirimir possíveis dúvidas dos procuradores das respectivas Câmaras, "pellas noticias, que ambos tem da Situaçaõ e distancias das Comarcas" 53 .

A primeira notícia da presença do engenheiro em Minas Gerais, segundo documentos que me foi possível coligir, data de 5 de julho de 1711 exatos três dias antes da "Junta Geral" de ereção de Vila Rica. Tratava-se de uma Ordem régia em que the era solicitada a confecção de um "Mappa de todas estas terras", entre São Paulo, as Minas, Rio de Janeiro e a "Baya", para se distinguirem melhor as jurisdições que tocavam a cada uma, o que seria de particular interesse de Sua Majestade:

e para isto se obrar com mais acerto fará que o S. Mor [Sargento-mor] Engenhr.o Pedro Gomes Chaves faça um Mappa de todas estas terras, pois achando-se pouco opprimido de Trabalho, o poderá fazer, e para o conseguir, como convem, ha de ir a grandes distancias, e que the arbitre para estas diligencias, a quella ajuda de custo que parecer justa, e the declarará, que se fazer este Mappa, como se espera S. Magestade lho terá como hum particular Serviço para attender no seu adiantamento ${ }^{54}$.

Além do território, como já adiantamos, engenheiros militares como Pedro Chaves riscaram e participaram de construções e reformas de edifícios públicos e religiosos, como mais tarde, na década de 1740, destacar-se-ia o também sargento-mor e engenheiro militar José Fernandes Pinto Alpoim. Em Pitangui, segundo monsenhor Vicente Soares, Pedro Gomes Chaves foi solicitado por um tal "Velho da Taipa" a fornecer instruções e planos para se reedificar o corpo da lgreja da Penha. A então ermida estava insuficiente para os moradores, e deveria ser incorporada à lgreja Matriz como sua capela-mor. Atribuo a Pedro 
55. Cf. Luis Camilo de Oliveira Neto $(1940$, p. 83$)$.

56. Ibidem; grifo nosso

57. Cf.APM SC 18, f. 75 ; grifo nosso.
Gomes Chaves, por essas indicações (certamente há outras), importante atuação na difusão de conhecimentos, doutrinas e práticas arquitetônicas e povoadoras (urbanísticas) no território mineiro. Para melhor avaliação dessa responsabilidade, seriam necessários estudos mais aprofundados, incluindo a formação e demais realizações do engenheiro na metrópole e na colônia. Vimos como os objetivos metropolitanos residiam na conservação, no sossego e no aumento dos povos e das povoações, para os quais eram estratégicas a prudência e a capacidade de administradores, oficiais e engenheiros. Sob a consideração temperada das conveniências coloniais e metropolitanas, estava a "acomodação" dos moradores, subordinada à necessária manutenção dos "costumes" por eles reconhecidos, fundamentais no processo de escolha dos sítios para as novas fundações. Era preciso acomodar os moradores e as estruturas construídas em prol do grande projeto colonial dedicado a todo o território, mormente em Minas Gerais, geradora das maiores receitas da Fazenda Real. Era sobretudo necessário povoar, em concentrações urbanas acomodadas, convenientes, seguras e permanentes, que permitissem a regulação e o fisco, e a melhor conservação de todo o reino.

Luis Camilo de Oliveira Neto citou uma carta do governador D. Brás a Lisboa em abril de 1715 (não a encontrei), na qual se discorria sobre o fato de as povoações estarem "muito em princípio e que a experiência não tinha ainda provado a sua segurança" 55 . Eis porque o Conselho Ultramarino, baseado principalmente nessa informação, julgou "desaconselhável a edificação de Hospícios de Religiosos em Minas até que o tempo mostre que aquelas povoações tem permanência" 56 . Em outros territórios mineradores, a transitoriedade e o povoamento insuficiente ainda durariam mais do que em Minas Gerais. Enquanto em Minas as povoações já indiciavam, segundo Sylvio de Vasconcellos, seu "período áureo", a metrópole ainda encontrava dificuldades para consolidar a "permanência" e a "segurança" em outros domínios, sobretudo naqueles de fronteira, sujeitos constantemente a ameaças de invasão. Assim, em 12 de Março de 1741, o rei D. João V estabelecia concessões para as povoações da Comarca de Cuiabá - "confinadas" com "as das Indias de Hespanha" -, porque "seria conveniente $q$ ' aos habitadores della [se] fizesse [...] algum favor nos tributos e direitos para lhe[s] facilitar a entrada e permanencia na terra por ter esta muito pouca gente" ${ }^{\prime \prime}$.

E os problemas de segurança quanto a invasões não se restringiam aos limites de fronteira com os espanhóis. $O$ litoral e as entradas por ele também deveriam ser melhor guardadas, visando a permanência e a conservação de todas as "Conquistas". Tanto que o próprio governador D. Brás, retrocedendo agora a 24 de setembro de 1713, em carta bastante interessante, sugeria a Sua Majestade a "conveniente" construção de uma "Cidadela" entre a "Villa de Sanctos" e a cidade de São Paulo, no cimo plano da serra, 
chamada de Fernando Piacaba, a qual he de hua altura prodigiosa, naõ lhe deixando maes, que hum caminho pello qual se pode montar, e taõ estreito, que ha partes onde nam cabe mais de hum homem, e na mais Larga tres de frente, e dehúa, e outra parte Saõ despenhadeiros inacessiveis, e asperissimos; em cima da Serra esta húa plaina donde fora muy conveniente Se fizesse húa Cidadela, o que com pouca despeza Conseguir porque Sendo de terra, que he o com que Se edifica nestas partes nam deixara de Ser duravel, e forte como tem mostrado a experiencia e na situação Referida podia Resistir ao mayor poder do mundo ${ }^{58}$.

Continuando a carta, o governador - que demonstrou possuir conhecimento teórico e prático das artes militares ${ }^{59}$ e também das recomendações para a "conveniente" implantação de fortificações e povoações - afirmava o quanto esta "Cidadela Segurava a Cidade [São Paulo] e todo o pais da Serra acima ficando impenetrável da parte da Villa de Sanctos que he a única por onde Se pode Recear qualquer invasão". Se a experiência e a prudência de Antonio de Albuquerque the permitiram adaptar uma fortificação no Grão-Pará, bem como relevar (conhecedor que era das virtudes da adequação) o sítio "não muito acomodado" de Vila Rica, o cabedal de D. Brás, seu sucessor, o levou a especular uma "Cidadela" - resistível ao "maior poder do mundo" - para a melhor conservação das conquistas e dos povos.

Estava aberto, a partir de 1711, o ininterrupto processo de implantação e adequação de Vila Rica ao sítio "não muito acomodado". Oportuno destacar que nesse momento não havia as edificações que destacaram Ouro Preto como paradigma urbanístico e arquitetônico, patrimônio da humanidade, obras empreendidas principalmente no decurso do século XVIII. Quaisquer que fossem a estratégia, os procedimentos e as técnicas de adaptação ao sítio e às preexistências construídas, seriam realmente inevitáveis as incomodidades urbanas. Sylvio de Vasconcellos sinalizou como algumas ruas se desenvolveram coleantes aos morros, enquanto outras desafiaram ladeiras íngremes, resultados nem sempre amistosos entre desejo de "regularidade geométrica" e necessidade (regular) de adequação.

Várias são as evidências de que a doutrina do decoro foi fundamental ao processo de consolidação da acomodação, da comodidade e sobretudo da decência das povoações em Minas Gerais. Finalidades de um urbanismo conveniente, para o qual serviram desde reformas, reparos e "correições" urbanas cotidianamente necessárias, implantações de novos edifícios e arruamentos, até intervenções mais complexas, como aquelas pelas quais passou Vila do Carmo para melhor acomodar seus moradores e, a partir de 1745, sediar o Bispado condignamente. A fábrica artístico-construtiva setecentista que levou a cabo essas intervenções sustentava-se, direta ou indiretamente, nas atividades desempenhadas pelos "vereadores" das câmaras - não por acaso definidos no princípio do século XVIII como os "zeladores das conveniências do povo"60.
58. Cf. APM SC 04, f. 176, $176 \mathrm{v}$.

59. Beatriz Bueno relatou dois fatos bastante curiosos que colaboram com o reconhecimento da experiência militar de D. Brás. Sob suas ordens (então retornado das conquistas e comandante da praça de Almeida na década de 1730), o sargento-mor e engenheiro José Fernandes Pinto Alpoim (ainda não enviado para a colônia), teria se disfarçado de "mendigo" para fazer levantamento de um forte que os espanhóis estavam construindo na fronteira; $\mathrm{e}$, outra vez, disfarçado de "camponês", para analisar um comboio militar espanhol que seguia em direção à praça de Alcântara.Cf. Beatriz Bueno (2001, p. 527).

60. Cf. Raphael Bluteau, s.v. VereAdôR (1712, v. 8, p. 437). 


\section{REFERÊNCIAS}

FONTES MANUSCRITAS

Arquivo Público Mineiro (APM), Seção Colonial (SC)

APM SC 03, f. 2.

APM SC 03, f. 3 .

APM SC 04,f. 176, 176v.

APM SC 06, f. 3-5.

APM SC 06, f. 9, 9v.

APM SC 06, f.14, 14v, 15. Criação da Vila de Nossa Senhora do Ribeirão do Carmo.Vila do Carmo, 8 abr. 1711.

APM SC 06, f. 20, 20v, 21. Termo da erecçao de Via Rica.Vila Rica, 8 jul. 1711.

APM SC 06, f. 35.

APM SC 09, f. 20v-22. Instrucçaõ deque há deuzar o Sargento mor Ingenheiro Pedro gomes chaves que hora hemandado a Pitangui.Vila do Carmo, 8 abr. 1714.

APM SC 09, f. 20v.

APM SC 09, f. 30.

APM SC 09, f. 18v, 19, 19v.

APM SC 09, f. 21, 21v..

APM SC 09 f. 22.

APM SC 09, f. 26, 26v.

APM SC 18, f. 75 ,

APM SC 86, f. 33. Elevação de Vila do Ribeirão do Carmo a cidade de Mariana. Lisboa, 23 abr.1745.

APM SC 86, f. 33 .

Arquivo Público Mineiro (APM), Seção Secretaria de Governo (SG)

APM SG Cx. 01, doc. 01 (doc. avulso), f. 1-2v, (cópia). Carta régia de nomeação de Antonio de Albuquerque Coelho de Carvalho. Lisboa, 9 nov. 1709.

OBRAS IMPRESSAS

ANASTASIA, Carla Maria Junho; SILVA, Flávio Marcus da. Levantamentos setecentistas mineiros, violência coletiva e acomodação. In: FURTADO, Junia Ferreira (Org.). Diálogos oceânicos: Minas Gerais e as novas abordagens para uma história do império ultramarino português. Belo Horizonte: UFMG, 2001. p. 307-332. 
ANTONIL,André João [João Antônio Andreoni]. Cultura e opulência do Brasil,por suas drogas e minas (1711). Rio de Janeiro: IBGE/Conselho Nacional de Geografia, 1963.

ARAUJO, Renata Malcher de. Cidades da Amazônia no século XVIII: Belém, Macapá, Mazagão. Porto: Editora da Faculdade de Arquitectura do Porto, 1998.

BANDEIRA, Manuel. Guia de Ouro Preto. Rio de Janeiro: Ediouro, 2000.

BARBOSA, Waldemar de Almeida. Catas Altas. Dicionário bistórico e geográfico de Minas Gerais. Belo Horizonte: Itatiaia, 1995.

BASTOS, Rodrigo Almeida. A arte do urbanismo conveniente: o decoro na implantação de novas povoações em Minas Gerais na primeira metade do século XVIII. Dissertação (Mestrado em Arquitetura)-Escola de Arquitetura da Universidade Federal de Minas Gerais. Belo Horizonte, 2003.

BASTOS, Rodrigo Almeida.A mais bela vista do Brasil: paisagem vista do Largo de Coimbra, Igreja de São Francisco de Assis, Serra e Pico do Itacolomi, Ouro Preto, Minas Gerais. Colóquio Ibero-americano: Paisagem cultural, patrimônio e projeto: desafios e perspectivas, 1. Belo Horizonte, UFMG-MAPCS; CEDODAL; CREA; 9 a 12 de agosto de 2010.

BASTOS, Rodrigo Almeida.Alpoim e o zimbório da Igreja Matriz do Pilar em Ouro Preto: engenho e simbolismo na arquitetura religiosa do século XVIII em Minas Gerais. Revista Desígnio. Revista de história da arquitetura e do urbanismo. Universidade de São Paulo. Faculdade de arquitetura e urbanismo. São Paulo,Annablume, 2009, set./ 2009, p. 113-136.

BASTOS, Rodrigo Almeida. Regularidade e ordem das povoações mineiras no século XVIII. Revista do IEB/USP. Revista do Instituto de Estudos Brasileiros da Universidade de São Paulo. São Paulo: Ed. 34, n. 44, p. 27-54, fev. 2007.

BLUTEAU, Raphael. Vocabulário portuguez, e latino, aulico, anatomico, architectonico, bellico, botanico... Coimbra: Real Collegio das Artes da Companhia de Jesu, 1712. $10 \mathrm{v}$.

BRÊTAS, Rodrigo.Traços biográficos relativos ao finado Antônio Francisco Lisboa, distinto escultor mineiro, mais conhecido pelo apelido de Aleijadinho. In:VEIGA, José Pedro Xavier da. Ephemérides mineiras (1664-1897). Belo Horizonte: Centro de Estudos Históricos Culturais/Fundação João Pinheiro, 1998.v. 3 e 4, 18 de Novembro, p. 993-996.

BUENO, Beatriz Piccolotto Siqueira. Desenbo e desígnio: o Brasil dos engenheiros militares (15001822). Tese (Doutorado)-Faculdade de Arquitetura e Urbanismo, Universidade de São Paulo, São Paulo, 2001.

CÓDICE Costa Matoso. Coleção das notícias dos primeiros descobrimentos das minas na América que fez o doutor Caetano da Costa Matoso sendo ouvidor-geral das do Ouro Preto, de que tomou posse em fevereiro de 1749 , \& vários papéis. In: FIGUEIREDO Luciano Raposo de Almeida; CAMPOS, Maria Verônica (Coord.). Belo Horizonte: Fundação João Pinheiro-Centro de estudos Históricos e Culturais, 1999. 2 v. (Mineiriana, Obras de Referência).

COELHO, José João Teixeira. Instrução para o governo da capitania de Minas Gerais. Belo Horizonte: Fundação João Pinheiro/Centro de Estudos Históricos e Culturais, 1994.

COUTO, José Joaquim do. Memória sôbre as minas da capitania de Minas Gerais, suas descripções, ensaios, e domicilio proprio; à maneira de itinerário com um appendice sobre a nova lorena Diamantina. Revista do Archivo Público Mineiro, ano 10, 1905.

FONSECA, Cláudia Damasceno. Pouvoir, villes et territoires, Pouvoirs, villes et territoires: genèse et representations des espaces urbains dans le Minas Gerais (Brésil), XVIIIe - début du XIXe 
siècle.Tese (Doctorat en Histoire et Civilisations). École des Hautes Études en Sciences Sociales, Paris, 28 nov. 2001, p. 50.

FORTIFICAÇÕES da Amazônia,As. In Annaes da Biliotbeca e Archivo Público do Pará. [s. 1.]: [s. n], 1905, p. 241-244.

GONZAGA, Luis. Tratado da Archi[te]ctura. [Exame] Militar. [17--?). (BIBLIOTECA NACIONAL DA AJUDA, Códice "E”, 46-VIII-23).

HANSEN, João Adolfo.Artes seiscentistas e teologia política. In:TIRAPELI, Percival (Org.). Arte sacra colonial: barroco memória viva. São Paulo: UNESP/Imprensa Oficial do Estado, 2001. p. 180189.

OLIVEIRA NETO, Luis Camilo de. João Gomes Batista (nota preliminar). Revista do Serviço do Patrimônio Histórico e Artístico Nacional, Rio de Janeiro, n. 4, 1940.

REGIM.T T $^{\circ}$ ou Instrucção que trouxe o Governador Martinho de Mendonça de Pina e de Proença (Lisboa, 30 out. 1733). Revista do Archivo Público Mineiro, Ouro Preto, ano 3, 1898.

ROSSA, Walter.A cidade portuguesa. In: PEREIRA, Paulo (Org.). História da arte portuguesa. Lisboa: Círculo de Leitores, 1995. v. 3

SOARES, Vicente. A História de Pitangui. Belo Horizonte: [s. n.], 1972.

VITERBO, Francisco Marques de Sousa. s. v. Chaves, PedRo Gomes. Diccionario historico e documental dos architectos, engenbeiros e constructores portuguezes ou a serviço de Portugal. Lisboa: Imprensa Nacional-Academia das Sciencias de Lisboa, 1922. 2 v.

TRINDADE, Raimundo. São Francisco de Assis de Ouro Prêto: crônica narrada pelos documentos da ordem. Rio de Janeiro: Ministério da Educação e Saúde, 1951. (Publicações da Diretoria do Patrimônio Histórico e Artístico Nacional, $n .{ }^{\circ}$ 17).

TEIXEIRA, Manuel C.;VALLA, Margarida. O Urbanismo português. Lisboa: Livros Horizonte, 1999.

VASCONCELLOS, Diogo de. Historia antiga das Minas Gerais (1703-1720). Rio de Janeiro: Imprensa Nacional, 1948. 2 v. Cf. também BANDEIRA, Manuel. Guia de Ouro Preto. Rio de Janeiro: Ediouro, 2000.

VASCONCELOS, Salomão de. Como nasceu Ouro Preto, sua formação cadastral desde 1712. Revista do Patrimônio Histórico e Artístico Nacional, Rio de Janeiro, n. 12, p. 171-232, 1955.

VASCONCELOS, Salomão de. Os primeiros aforamentos e os primeiros ranchos de Ouro Preto. Revista do Serviço do Patrimônio Histórico e Artístico Nacional, Rio de Janeiro, n. 5, 1941.

VASCONCELLOS, Sylvio de. Vila Rica: formação e desenvolvimento - residências, São Paulo: Perspectiva, 1977.

VASCONCELLOS, Sylvio de. Formação das povoações de Minas Gerais. In: Arquitetura no Brasil,pintura mineira e outros temas. Belo Horizonte: Escola de Arquitetura da UFMG, 1959. p. 1-6.

VEIGA, José Pedro Xavier da. Ephemérides mineiras (1664-1897). Belo Horizonte: Centro de Estudos Históricos Culturais. Fundação João Pinheiro, 1998. 4 v.

Artigo apresentado em 1/201 1. Aprovado em 12/201 1. 